\title{
United States Trade Policy at
}

\section{the Crossroads}

\author{
Jagdish N. Bhagwati
}

\begin{abstract}
$\widetilde{\mathfrak{d}}$ HE popular perception, and the objective reality, of United States trade policy is that it is in a state of flux; indeed, it may have taken a turn for the worse. ${ }^{1}$

It is not just that the Administration of the United States has succumbed to mounting demands for protection against imports by negotiating a number of significant export restraints. Nor is it that the 'unfair trade' provisions in American law for taking anti-dumping actions and levying subsidy-countervailing duties have been captured and misused by protectionists ${ }^{2}$ - even though less, perhaps, than in the European Community.

What is most disturbing is the weakened commitment of the United States to multilateralism, manifesting itself in a variety of new ways. ${ }^{3}$ The evidence of a fundamental change in trade policy is the new interest in regional arrangements and the departure from the accepted way of 'doing business' under the General Agreement on Tariffs and Trade (GATT) by asserting that demands can be made for unilateral trade concessions by others and enforced by threats of retaliation.
\end{abstract}

\section{NEW DIRECTIONS: ACTUAL AND POTENTIAL}

The origins of some of the changes can be traced back to the Trade Act of 1974 (which reflected, inter alia, the trade concerns arising from the weakness of the American dollar before the collapse of the Bretton Woods system). ${ }^{4}$ But the dramatic events that have marked a turning point in American trade policy are more recent. Two merit mention.

The United States-Canada Free Trade Agreement, finally approved by the two countries in 1988 , was a significant event. It had been preceded by the free trade

JAGDISH N. BHAGWATI: Arthur Lehman Professor of Economics and Professor of Political Science, Columbia University, New York, in the United States; previously Ford International Professor of Economics at the Massachusetts Institute of Technology, Cambridge (1978-80), having held a chair there since 1968. Professor Bhagwati is the author, inter alia, of Protectionism (1988), based on his Ohlin Lectures at the Stockholm School of Economics. 
agreement with Israel, but the special relationship the United States has with Israel, given their constituencies, made that an event of little predictive value. The free trade agreement with Canada is a different matter altogether, representing a conscious reversal of policy not to exploit the GATT's Article XXIV, which provides for departures from the principle of non-discrimination to form free trade areas or customs unions. It signalled that regionalism, or plurilateralism (as distinct from unconditional most-favoured-nation [MFN] treatment), was now okay for the United States to pursue. ${ }^{5}$ The coincidence with the move by the European Community to complete its internal market by the end of 1992 has led, in turn, to widespread fears that multilateralism is coming to an end - one symptom of which was Lester Thurow's celebrated Davos pronouncement, 'GATT is dead'. 6

The other significant event was the passage by the United States Congress of the Omnibus Trade and Competitiveness Act of 1988 - in the face of strenuous resistance by the Administration to certain of its provisions. Better called the Ominous Act of 1988, this piece of legislation tightened, in various ways, the 'unfair trade' laws of the United States with respect to anti-dumping actions and subsidy-countervailing duties.

What has attracted most attention, however, is the extension of Section 301 of the Trade Act of 1974 to create a blunt instrument of trade policy. Section 301 had been used, until then, mainly to remedy treaty-defined 'unfair trade practices', determined as such under multilateral procedures when GATT obligations were in question. It has now been turned into a 'crowbar' that could, with the aid of threatened tariff retaliation, pry open foreign markets determined by the United States to be closed to its exports and could be used, also, to remove foreign "unfair trade' practices, not defined as such by any treaty whatsoever but determined by the United States to be 'unreasonable' and impacting adversely on its trade. ${ }^{7}$

Thus with one unhappy passage of legislation, the United States Congress has given legitimacy to unilateralism in defining America's trade rights, in determining their violation and in meting out punishment to secure satisfaction. This marked a departure from key principles that the GATT reflects: in particular, that trade rights are defined by, and are available to, all GATT member countries and all GATT member countries subject themselves to the same dispute-settlement procedures over alleged violations of those trade rights.

The 1988 Act has also marked a departure from the conventional GATT approach of 'first difference' reciprocity in bargaining over 'concessions' in multilateral trade negotiations. In place of 'balanced' mutual reductions of barriers to trade, as in seven rounds of GATT negotiations since 1947, the United States Congress appears now to have embraced a novel method of moving to freer trade in particular situations: ask others to liberalize using not the inducement of one's own trade concessions but the threat to suspend one's trading obligations if the demands are not met. 
This is the approach of the so-called 'Super-301' provisions of the 1988 Act (actually set out in Section 310). It is an approach that has caused much consternation, both among domestic critics and foreign countries. It permits, at the end of a mandated course of actions, entire countries - not just individual industries, as under Section 301 of the 1974 Act - to be castigated as unfair traders. Initially, the Super-301 provision requires the United States Trade Representative (USTR) to identify, in practice on the basis of a survey of 34 countries and two trading blocs, foreign trade practices whose elimination is likely to increase American exports significantly. The process thus results initially in the identification of 'priority' practices and 'priority' countries.

On 25 May 1989 the first stages of the process reached a climax when, following the USTR's report, President Bush named Brazil, India and Japan as 'priority countries' and specified five areas of 'priority practices' that would be investigated further. The different stages will now face other mandatory deadlines. If, after twelve to eighteen months of investigation and negotiation (where agreed by the named countries), the USTR finds the 'priority practices' to be 'unfair', the United States may take retaliatory action. The result of all of this has been an electrifying recognition of a definite shift in the trade policy of the United States.

What could be a final blow is threatened by the vociferous proponents of 'managed trade'. Their major policy initiative was a report submitted on 10 February 1989 by the President's Advisory Committee on Trade Negotiations. Focusing on Japan, the report asked for a 'results-oriented' trade policy, thus opting for what I have called a 'fix-quantity' regime, by contrast to the 'fix-rules' regime that the GATT represents.

The popularity of the report on Capitol Hill and the fact that it represents the sentiments and policy views of an influential set of chief executives in the American business community are causes for concern. So were early reports of approbation by Carla Hills, the United States Trade Representative in President Bush's Cabinet, which were subsequently denied and attributed to erroneous reporting. It is an open and disturbing question whether, in fact, 'managed trade' will sneak its way into United States trade policy, past Ambassador Hills's emphatic rejection, by judging the 'good behaviour' of Japan and other targeted countries by 'how much' they import - and how much of it is imported from the United States and from particular American industries. ${ }^{8}$

These changes in the trade policy of the United States coexist with the undoubted and considerable commitment of the Administration to the success of multilateral efforts, in the Uruguay Round of multilateral trade negotiations in Geneva, to liberalize agricultural trade and trade in services as well as extend GATT rules to other 'new areas'.

American trade policy therefore presents two faces. But with governments which are not monolithic that is not a sign of schizophrenia. In the case of the 
United States, the multilateral initiatives are essentially those of the Administration, while the shifts to unilateralism have been driven by the Congress. The latter reflect, in turn, a variety of forces, among them lobbying pressure from constituencies and, too, the appeal of diverse arguments that seem to provide plausibility to the notion that America deserves unilateral trade concessions from her trading rivals, extracted if necessary by threats of tariff retaliation.

In the rest of this article, I therefore consider, in the next section, the general factors that have prompted the shifts in United States trade policy. In the third section, I consider the many arguments that are in currency, implicitly or explicitly, to justify the demands for unilateral reductions of trade barriers by others. Next I examine the appropriateness of the Section-301 and Super-301 methods used to extract those unilateral concessions. I conclude briefly with the questions of 'managed trade' and regionalism.

\section{FORCES UNDERLYING THE SHIFTS IN UNITED STATES TRADE POLICY}

In understanding the new embrace of regional initiatives and aggressive unilateralism in opening foreign markets, and in seeking the removal of foreign trade practices considered unilaterally to be unreasonable and hence unfair, it is important to appreciate the critical role played by the acceleration of import protectionism during the first term of the Reagan Administration. ${ }^{9}$

The increased demands for import protection that surged in the United States Congress were not the run-of-the-mill kind that arise from time to time as random pressures on specific industries from imports and are translated in the political arena into demands for relief from foreign competition. They were over a much wider spectrum of industries. Their potency derived not merely from the pressure of constituents, reflecting sectional interests, but from the increasing sense in the Congress that the social good required support for troubled industries. Let me elaborate.

\section{The Balance of Payments}

1. The over-valuation of the American dollar put significant pressure for adjustment in the traded activities of the American economy - making non-traded activities generally more profitable at the expense of the traded ones.

Mounting constituency pressure for relief from imports was an inevitable political outcome. It was handled inaptly by the Administration during the first Reagan term. Until the Plaza Agreement, the appreciation of the dollar was regarded with indifference, seen simply as a consequence of the attractiveness of the American economy for foreign investable funds. The possibility that there 
could be, even in that case, serious adjustment problems imposed on the economy - as with the 'Dutch disease' problem - because of the magnitude of the resource reallocation required was not addressed.

The 'high-track' export restraints that followed were thrown as crumbs to satisfy protectionist demands. But the crumbs turned into loaves, marring the free-trade image, and also the track record, that the Reagan Administration wanted. ${ }^{10}$

2. But the 'balance-of-payments' situation, in the shape of the trade deficit that persisted in spite of the significant post-Plaza realignment of the dollar, fostered a growing feeling that the trade deficit was unsustainable, had to be eliminated and could not be tackled by exchange-rate realignment. The broader American interest required, therefore, that trade policy had to be deployed to address the trade deficit.

It is true that the unsustainability of the trade deficit and its elimination as a goal for the United States (whether in its own interest or that of countries 'more in need of capital') are issues that are arguable, to say the least, and have been argued extensively. But the notion that exchange-rate changes cannot impact any more on the trade deficit has drawn somewhat greater strength from the empirical observation that the realignment of the dollar failed to reduce the trade deficit anywhere near as quickly and as much as many had hoped. It accordingly needs commenting upon. Two points should be made.

First, a cliché, but an important one. If excess spending continues, expenditureswitching policies, such as exchange-rate devaluations, will fail to produce more than ripple effects on the trade deficit. ${ }^{11}$ If the budget deficit persisted, and no significant reduction in spending occurred in the private sector, the realignment of the dollar could not be expected to work.

Second, a novel consideration. If local prices do not rise, a devaluation cannot induce a switch of expenditure away from imports. Much was made, in the early years after the Plaza Agreement, of the failure of the 'pass-through' effects of the currency realignment. Prices of imported goods did not rise by the amount of the dollar devaluation or, at least, not as much as 'normal'. A search for explanations started among macro-economists. The more interesting among them was the notion that investments, once made, would lead to price-setting behaviour to hold onto markets. Japanese firms, having invested in the high dollar for sales in American markets, would tenaciously cut prices when the dollar fell, rather than close down and move out. This notion of 'hysteresis', and lack of symmetry around a change back and forth, may have some merit insofar as the dollar was high for a long period and investors may not have foreseen the magnitude of the dollar's fall. ${ }^{12}$

But a natural and plausible explanation, pertinent to the discussion of trade policy, is one that the macro-economists forgot to note, perhaps because their conventional thinking had not caught up with the way non-tariff measures are used 
in developed countries generally and in the United States in particular to deal with 'disruptive' imports. ${ }^{13}$ This was simply that, as the dollar had long remained high, Japanese (and Far Eastern) exports had come to be heavily afflicted by exportrestraint arrangements in various forms. This meant that there was often a substantial scarcity premium on Japanese goods. If the dollar was devalued, the devaluation would first cut into this premium, with the final price to American consumers unaffected. Only after the devaluation had exceeded this premium would an impact on final prices be seen. That is to say, the pass-through effects would be abnormally low at the outset, until the premia were absorbed. ${ }^{14}$

That this hypothesis has explanatory power is supported by the facts that Japanese goods were heavily restrained, that the dollar was devalued mainly against the yen and that the pass-through effects improved after the dollar devaluation had become substantial. But it is additionally supported by disaggregated industry studies undertaken in Japan. ${ }^{15}$

By ignoring the linkage between protection and exchange-rate inefficacy, analysts have encouraged the erroneous idea that protection is necessary because exchange-rate changes are ineffective. We are in danger, then, of experiencing a vicious circle: protection leads to the reduced efficacy of exchange-rate changes; in turn, the inefficacy of exchange-rate changes leads to protection.

But it is also necessary to remind politicians that if they think exchange-rate changes are inefficacious because 'prices no longer matter', the same objection could apply to protection. Both are expenditure-switching policies (although they are not identical insofar as the exchange-rate change affects exports as well). In addition, neither policy can work unless it differentially affects domestic savings and investment, so as to produce an excess of the former over the latter at the margin. ${ }^{16}$ Otherwise a lasting impact on the trade deficit is not possible. ${ }^{17}$

\section{The Double Squeeze}

The adjustment problem for the traded industries in the United States has been further accentuated by a 'double squeeze'. ${ }^{18}$ The growth of exports from Japan and the Pacific 'Gang of Four' (Hong Kong, Singapore, South Korea and Taiwan) and the less spectacular but still impressive export performance of other newly industrializing countries, such as Brazil, and of the newly exporting countries, such as Malaysia and Thailand, have created problems for specific industries in the developed countries, obliging them to adjust to those changes.

A country that grows more rapidly than others will, on average, export at a volume and rate of growth that is hard for the other countries to accommodate without complaints from the domestic industries that must bear the brunt of the adjustment. Japan has been up against this phenomenon since the 1930s. Even then, when Japan was not yet dominant, Japanese diplomats were scurrying around negotiating 'voluntary' export restraints - on pencils, electric lamps, 
safety matches and other products - with the United States, Britain, Australia and other trading partners, partners among whom a bilateral surplus in trade with Japan was common. The present surplus situation has compounded Japan's difficulties; but even if her surplus were to disappear, she would continue to attract the protectionist ire of disaffected competitors. ${ }^{19}$

\section{De-industrialization and National Interest}

The protectionist fall-out, however, has come not merely from troubled industries seeking relief. There has been the national-interest concern that America is threatened with de-industrialization and that this, in turn, will damage the economic well-being of the United States.

The Democrats, in particular, fell easy prey to these views. For instance, in the 1984 Presidential election campaign in the United States, the Democratic candidate Walter Mondale invoked images of Americans reduced to flipping hamburgers at McDonalds while the Japanese overwhelmed the country's industries. He might have invoked, with greater irony, a picture of American kids rolling rice cakes at sushi bars.

The fear of de-industrialization also agitated the leaders of trade unions in declining, protection-seeking industries. Sol Chaikin, for example, of the International Garment Workers' Union, protested in an article in Foreign Affairs: 'Because there are relatively few well-paying jobs in the services sector, an economy devoid of manufacturing would also necessarily experience a general decline of living standards. . . Unrestricted trade and the investment practices of the multinationals . . can only lead to an America ultimately devoid of manufacturing. 20

The effect was to make life easier for those seeking protection. These views made it less difficult for politicians to respond affirmatively to narrower interests seeking protection. Congressmen voting for protection could feel comfortable in their conviction that they were acting, not as politicians responding to the narrow sectional interests of their constituents, but as statesmen safeguarding the national interest.

From an objective point of view, however, the arguments advanced in support of the view that de-industrialization has deleterious consequences are sufficiently tenuous to make the recent 'manufacturing matters' school of worriers in the United States as hard to side with as the members of the better-known and earlier school of de-industrialization in the United Kingdom, led by the late Nicholas Kaldor, the distinguished Cambridge economist and intellectual of the Labour Party. ${ }^{21}$ Let me address some of the principal arguments of the two schools.

Some contend that manufacturing plays an 'integral role' in the American economy in the shape of 'important linkages to the broader economy'. ${ }^{22}$ But linkages in the shape of input-output relationships reveal nothing about the 
desirability of policy intervention to correct market failure. It is commonplace among non-economists to infer externalities from linkages. It is also a common non sequitur. ${ }^{23}$

It is often said that because American manufactures 'constitute a significant source of demand for the output of other industries', an increase in manufacturing unemployment would create increased unemployment in other related industries ${ }^{24}$ and, therefore, manufactures must be supported. But that is an argument which can be easily turned on its head. Would it not be sensible to reduce the size of an industry that can cause such sizeable disruption? Besides, even accepting the form of the argument, one must build a plausible counter-factual to judge the matter. If manufactures go down, what goes up; and what then would be the new linkages?

Furthermore, the notion that services are complementary to manufactures has been used to argue that the promotion or defence, at a minimum, of manufactures is essential. The collapse of one would lead not to a 'post-industrial' service economy but to something else (presumably more primitive, instead of progressive and pleasurable). Now let me quote from the chief proponents of this view (peculiar to the American school and, to my knowledge, foreign to the British school's way of thinking which saw manufactures as being a substitute to services):

'There are . . linkages in the economy, such as those which tie the crop duster to the cotton fields, the ketchup maker to the tomato patch, the wine press to the vineyards (to return our focus on agriculture). Here the linkages are tight and quite concrete. . Beyond the limit of possible recommendations provided by the bounded space, the linkage is a bind, not a junction or substitution point. Offshore the tomato farm and you close or offshore the ketchup plant. No two ways about it' (emphasis added). ${ }^{25}$

When I first read this assertion, as I remarked in my Ohlin Lectures, I was eating my favourite Crabtree \& Evelyn marmalade and had not realized that England grew her own oranges! ${ }^{26}$

Similar arguments have come from other proponents of manufactures. For instance: ${ }^{27}$

‘. many industries that feature prominently in visions of the "postindustrial" economy, such as education, banking and communications, are demanded in significant part by the manufacturing sector. The health of these progressive parts of the services sector is therefore tied to the performance of American manufacturing firms.'

This statement confuses linkages with physical proximity or, at least, national production of producer services. But linkages in most modern services need not be either. Thanks to technical change, many modern services can now be delivered without the physical proximity of the supplier to the user: many are what are now called 'disembodied' or, better still, 'long-distance' services which can be delivered over the wire. ${ }^{28}$ Technical change has greatly reduced the degree of 
local establishment necessary to deliver services to users even when efficient supply requires physical proximity. The assumption that there is a strong physicalproximity linkage which makes it impossible to supply producer services to manufacturing establishments elsewhere was never wholly true. Now it is almost fanciful. It derives almost certainly from an archaic haircuts-as-services conception of the services sector.

Turning, then, to more serious arguments for favouring the manufacturing sector, one must reckon with the different claims - implicit and explicit - of market failure. A particularly appealing one has resulted from the recent developments in the theory of trade in imperfectly competitive product markets. With sufficiently large economies internal to the firm, oligopolistic market structures can emerge. It follows that prices will generally not measure true costs, that excess profits will emerge and that intervention in support of one's own industry can shift some excess profits away from foreign firms towards the domestic industry in question. ${ }^{29}$

These notions are scientifically interesting and have attracted well-deserved attention. But if they are used to support the promotion of manufactures, as has often been the case in Washington, it is necessary to note several compelling objections.

(a) The profit-shifting argument has a predatory flavour. It can therefore lead to retaliation. Once that happens, everyone can be a loser. Certainly, the world trading regime would be a loser. Trade battles, even when settled, can leave scars, making it easier for protectionists to achieve their self-serving goals.

(b) What is more, the argument pre-supposes that there are in fact significant rents to shift, but recent empirical analysis suggests that this is not so. ${ }^{30}$

(c) The question of sizeable increasing returns to scale to the firm can also be investigated empirically. Here again, the latest econometric findings for American and European industry indicate that there is very little evidence of internal economies even at the 'two-digit' level of industries, leaving one to wonder whether they exist in a significant degree at the level of individual firms. ${ }^{31}$

(d) Finally, if a special case is to be made for favouring manufactures because of the 'strategic' profit-sharing theory, it is pertinent to note that some in developing countries currently cite that very theory to say that modern services are characterized by substantial economies of scale and hence freer trade in services should be rejected. Obviously, there is no shortage of pressure groups who want protection and no shortage, either, of theoretical 'beneficial-protection' arguments that pressure groups will embrace (without detailed empirical justification) to further their cause. In any event, it is inconsistent for the makers of trade policy in the developed countries to use notions of 'strategic' trade policy (based on economies-of-scale arguments) to 
pursue their own goals while denying them to the developing countries whom they castigate as 'obstructionist' in negotiating an agreement on trade in services. Must economies-of-scale arguments be used only by those with scale (in terms of political power)?

Now for the overriding question of externalities. Do manufactures just have sex appeal to those who have never been close to a blast furnace or do they have unusual externalities, giving differentially more to us than they take from the national pie?

Externalities are a phenomenon that many economists feel must exist and may even be important. Serendipity and the fact that its rewards are not generally appropriable by those who act as catalysts testify to the belief that we are talking about something tangible. But it is so hard to identify the differential significance of externalities within specific activities that many economists have tended to walk away from the concept for policy-making purposes, arguing that they are the last refuge of the scoundrel seeking special favours, perhaps even the first refuge. ${ }^{32}$

By contrast, politicians have little trouble deciding what sector or industry has unusual externalities and, as a result, is important to defend and even expand. Manufactures have been the beneficiaries of their attention in developing countries and from the members of the British and American de-industrialization schools. So have, of late, high-technology industries where politicians believe that having them must be important for the economy because they are at the forefront of modern technology. ${ }^{33}$

It is difficult to find sufficiently convincing evidence to support the case for promoting manufactures, or specific components thereof like high-technology industries, on grounds of unusual externalities. Something can be said, though.

1. The econometric studies cited as showing that internal economies of scale are not important in American (and European) industries also show that external economies are important. These external economies are further related to the overall size of the manufacturing sector ${ }^{34}$ But the authors could equally have used the overall size of the economy or the size of the manufacturing sector plus the modern financial sector and turned up the same result. (I have urged them to test the hypothesis in view of the significance of these distinctions for the current policy debate on the consequences of de-industrialization.) $)^{35}$

2. Does the fact that manufactures show a higher rate of increase in labour productivity than others indicate that they must be supported? This was the view implied in the so-called 'Verdoorn Law' that led Kaldor to recommend the 'selective employment tax' in the United Kingdom to tax employment in services and thus make hiring cheaper for manufactures. Kaldor was careful to imply, however, that there was an externality here, that some sort of 'learning by doing' operated in manufacturing. ${ }^{36}$ The mere fact of a higher increase in productivity in a sector is in itself not an argument for policy intervention to support the sector. To my knowledge, the British debate on Kaldor's thesis did not produce any 
compelling evidence that manufactures were characterized by a significant amount of such implied 'learning by doing' or other externality and that the amount was sufficiently higher than in other sectors (such as modern services) to warrant differential support of manufactures. ${ }^{37}$

3. Yet another argument, used in the American debate, has been that the manufacturing sector accounts for over 90 per cent of research-and-development (R\&D) expenditures in the United States. This cannot be an argument though for supporting manufactures against a market-induced decline unless it is shown that the social rate of return on this research-and-development expenditure exceeds that on other capital spending. Again, one cannot really argue without further analysis that, no matter why and therefore where this sector shrinks in terms of industry-wise and firm-wise composition, R\&D expenditures will shrink too. Maybe the shrinking will take place in firms which do not undertake research and development; it would in fact seem plausible that the R\&D-intensive firms will be larger and, if import competition is causing the shrinkage, the firms that exit will be those that are smaller and not engaged in research and development. Thus even this version of the 'productivity' argument for manufactures remains unproven.

4. Another argument is that for small ('infinitesimal') changes, a subsidy to manufactures will produce a negligible ('second-order') loss if manufactures do not have externalities, but that if they do the gain will be non-negligible ('firstorder'). Given equal ignorance, one should then subsidize manufactures. ${ }^{38}$ But there are problems with this argument. (i) Interventions are not infinitesimal. (ii) The argument further pre-supposes that the world is efficient except for the possible externality in manufactures. (iii) The argument may be equally applied to modern services, in which case the subsidizing of manufactures may do more harm than good. (iv) Even within manufactures, it is highly unlikely that externalities obtain for all manufactures: even an infinitesimal across-the-board subsidy to all of them can then produce a net loss.

Finally, mention must be made of the interesting recent revival in the United States of the argument, originally considered relevant to developing countries, that manufactures have to pay excess wages for identical labour, these excess wages representing a distortion that requires appropriate intervention to support manufactures. ${ }^{39}$ I find this personally satisfying since the argument was first developed by trade theorists in the 1960s and directly led to the major scientific developments in the theory of commercial policy during the post-war period.$^{40}$ It serves therefore an incidental but important purpose in refuting the claims sometimes made that, until the arrival in the 1980s of the theory of trade in imperfectly competitive product markets, free trade was regarded as the policy that 'economic theory tells us is always right'. ${ }^{41}$ I nevertheless remain sceptical. Why?

1. It may well be that, even if all of the excess wage rates in an industry were treated as reflecting a distortion, it may not do more than dent the cost of existing 
trade restrictions on manufactured imports. Thus a recent study of the welfare and employment effects of United States import quotas on steel and automobiles concludes that the benefit of removing the quotas, in the presence of wage distortions, continues to be large, although diminished. ${ }^{42}$ In short, for the United States, the degree of protection of key manufactures that may be justified as a second-best intervention to offset the maximal possible distortion from excess wage rates paid in these sectors appears to be well below what exists.

2 . But the real problem, in my view, is that the interpretation of the wage differentials as distortionary is not yet robust enough, in spite of the enormous and systematic analysis of the issue. The degree of disaggregation for both industries and occupations is much too high - although large by conventional standards to support the conclusions derived if the purpose is to provide actual policy support to industries and sectors with distortionary excess wages. Since the particular theory of wage distortions which Lawrence Summers et al. favour is that of efficiency wages needing to be paid to avoid shirking, ${ }^{43}$ it would be useful if careful and extremely disaggregated micro-economic studies were produced, at least for an excess-wage-ranked pair of industries, showing that indeed shirking explains the wage differential. I am particularly concerned because, a priori, it would seem to me that shirking on the job should be a lot easier in service industries such as banking and insurance than in assembly-line manufacturing where shirking by an individual may show up immediately in disruption of the process. Yet the deviation of the wage from the all-industry average, adjusted for variables such as age, experience and schooling, is +9.7 per cent for manufactures and -13.2 per cent for finance, insurance and real estate. ${ }^{44}$

3. There is a puzzle in that the inter-industry wage differentials are similar for different classes of occupations: 'The industry wage structure also seems to be similar for different types of workers. In industries in which one occupation is highly paid, all occupations tend to be highly paid. ${ }^{, 45}$ But it seems highly doubtful that technological differences between every pair of industries would make everyone, whatever their level of occupation, shirk more in one industry than in the other. Can it not be that here we are catching something else altogether possibly, the cost of living in different regions or the cost of labour migration to different regions and geographical-specificity of different industries? For example, all Englishmen going to India in the nineteenth century, regardless of occupational level, would have had to be paid a 'tropical' premium, a wage differential.

In short, it seems premature to make recommendations for sectoral-policy interventions on the basis of the empirical evidence available. If we are going to intervene selectively in favour of industries and sectors, especially when we know that selective interventions of this type cannot be insulated from capture and misuse, the standard of persuasion if not proof that we should expect greatly exceeds what we have before us. The jury is still out. 


\section{The 'Diminished Giant' Syndrome}

The payments difficulties and the 'double jeopardy' phenomenon may have produced the conditions for increased demand by sectional interests lobbying for protection and for increased supply by influential Congressmen thinking that protection would also be in the national interest. But the overall ethos favourable to protectionism came from the national psychology produced by America's relative decline in the world economy. This might be called the 'diminished giant' syndrome.

While the United States continues to be a dominant power, it has witnessed the erosion of its predominant status in the world economy as Japan has risen from the ashes and, too, as other Pacific countries have come to the fore.

The parallel with Britain at the end of the nineteenth century is dramatic. In both instances, the giant's diminution produced a protectionist backlash, sorely trying the pro-trade bias of the international regime. ${ }^{46}$ Walter Lippmann characterized this as the American Century. In the same vein, the nineteenth century was Britain's. As the century ended, Britain was gradually losing her political and economic preeminence. The twentieth century is ending similarly for the United States. Staffan Burenstam Linder has already announced the arrival of the Pacific Century. ${ }^{47}$

The diminution in Britain's preeminence in the world economy led to a rise in protectionist sentiments and to demands for an end to Britain's unilateralist embrace of free-trade principles. And the United States has followed the same path. The present-day sentiments on trade policy in the United States have been aimed pointedly at the newly successful rivals, just as their nineteenth-century British counterparts were. The United States and Germany were to Britain what the Pacific nations - Japan in particular - are to the United States today.

\section{'Fair Trade' and 'Level Playing Fields'}

Aside, though, from aiding the rise of old-fashioned import protectionism, the diminished-giant syndrome has prompted a significant shift in United States trade policy towards emphasis on 'fair trade'. One can argue cynically that words matter, as Orwell taught us, and it is easier to indulge protectionism if it is sold as a response to 'unfair trade' rather than undisguised in its true form. The emergence, or re-emergence, of the 'fair trade' obsession in the United States grew as import competition grew with the rise of the dollar; and the growth of Far East trade can certainly be explained partly in such terms.

But the diminished-giant syndrome also helped. It is relatively easy, when one's premier status is in jeopardy, to think that the success of one's rivals must be due to perfidy. Panic produces petulance. ${ }^{48}$ The persistent and pervasive belief that the countries in the Far East are 'not playing by the rules', and that 'level playing fields' must be established to compete with them, owes much to this syndrome. 
In fact, 'fair trade' and 'reciprocity' emerged as issues in an equal degree in Britain when she faced her own relative decline at the end of the nineteenth century. The rise in Britain during the 1870s and 1880s of the National Fair Trade League, the National Society for the Defence of British Industry and the Reciprocity Free Trade Association are events that make the American sentiments and actions of the last decade more easy to comprehend. ${ }^{49}$

\section{Growth of Export Interests}

Apart from the emergence of concerns over unfair trade, the other dramatic change, and indeed a novelty in the political economy of trade policy generally, has been the growth of export interests in the United States. ${ }^{50}$ This has given a special form, and a sharp edge, to the concerns over unfair trade and to the unilateralism that afflicts American trade policy today, while also explaining the embrace of regionalism and the thrust of positions adopted by the United States in the Uruguay Round negotiations.

Natural Forces - Interests and Ideology: The increasing globalization of economic activity, with the criss-crossing of investments among the major trading countries, has created a 'spider's web' phenomenon. The reaction of multinational enterprises (with global reach) to import pressures does not need to be the old-fashioned demand for import protection. This can, by spreading protection elsewhere and thereby affecting freer trade in the world economy, imperil the open trading system within which they can function best.

They now have another option. If they sell in other markets, as most do, they can also ease the pressure of competition on themselves by asking for, not higher import barriers against others, but lower import barriers by others. Aside from this providing an option that may equally relieve competitive pressures, it is also in keeping with the general multinational ethos and interests of achieving a freer world trading regime.

It has the added advantage that one might be able to fit it into the 'unfair trade' framework, if applied at the level of products, firms and industries (as necessary to one's argument). If protection against American exports of automobiles in a particular country is greater than American protection against that country's exports of automobiles, that leads to a plausible claim of 'unfair' competition.

Ideologically, this argument may also be shown to have support from trade theory on grounds of efficacy, not just fairness. International trade theorists have argued that, under large-enough scale economies to a firm, import protection can lead to the viability of one's firm at the expense of one's rivals, producing even the paradoxical phenomenon that import protection leads to export promotion. ${ }^{51}$ In essence, it is easy to see that if firms are identical, economies of scale yield irreversible gains (as when learning occurs); and if one firm has access to two markets and the other has access to only one because its market is closed to imports 
and the other's is not, the firm in the protected market will gain a permanent advantage. ${ }^{52}$ This may even be to social advantage (although this is not guaranteed).

The sudden popular awareness of this demonstration, ${ }^{53}$ brought out from the closet by younger trade theorists and put into the political arena, ${ }^{54}$ has lent critical ideological support to the export lobbies seeking outward reach in foreign markets and to Congressmen who see in this a justification for aggressively 'opening foreign markets'.

The combination of export interests and ideology has been a heady brew, enough to provide the momentum for the 'open foreign markets' thrust in United States trade policy. But export interests have profited equally from the payments difficulties discussed earlier. Just as the belief that import restrictions will cure the trade deficit refuses to die, rising ever again like Jaws in James Bond movies, so does its flip side: that lowering foreign trade barriers will cure the trade deficit. Those who make policy in Congress are doomed to believe it; and those who seek to export willy-nilly have not hesitated to exploit it.

Promoting the Lobbies: The growth of the export lobbies was encouraged by the Administration. Faced with the outbreak of import protectionism in the country and on Capitol Hill, the Administration back-tracked -- with the Plaza Agreement - on its international macro-economic position of benign neglect. The induced, and inevitable, realignment of the dollar was the safety valve that had to be opened.

Equally, the Administration saw in the nascent export lobbies the opportunity to provide a political offset to the (import) protectionist lobbies. By nurturing them, and expanding trade through measures aimed at 'opening markets', the Administration would take the political momentum away from the protectionists who would 'close markets'.

In essence, the Administration did this in two ways, one consonant with the tradition of multilateralism, the other not quite so. The former was to push energetically for a new GATT round of multilateral trade negotiations where barriers to trade in old and new sectors (agriculture and services) of export interest to the United States would be brought down. These efforts culminated in the current Uruguay Round negotiations. The other course was to embrace regionalism in the shape of the free trade agreement with Canada, a dramatic and visible 'trade-expanding' move and one which also, in its inclusion of agreements on services, was supposed to provide a spur to the Uruguay Round negotiations in the deliberations on trade in services.

The preceding analysis focused on the many factors that have been driving the United States in the directions of unilateralism and regionalism even while it is an active participant in multilateral negotiations. The following analysis now offers an evaluation of these shifts, starting with unilateralism. 


\section{ARGUMENTS FOR UNILATERAL CONCESSIONS BY OTHERS}

Unilateralism relates to three different issues: (i) seeking unilateral trade concessions from others; (ii) refusing to submit oneself, as under the GATT, to the same dispute-settlement procedures in determining violations of one's trade rights that one uses against others; and (iii) defining new 'unfair trade' practices, and hence new trading rights and disciplines, through unilateral specification and threatened punishment for non-compliance rather than by negotiated treaty.

I shall have something to say (in the next section) about the use of threats by the United States, as embodied in the new 301 provisions, to establish new disciplines. Here, however, I address the pervasive view that America is entitled to something for nothing from others - especially from the Far East and Japan - by way of trade concessions. This view certainly lends the cutting edge to the forms of unilateralism distinguished above.

Economists have generally believed that unilateral trade liberalization by oneself is good. There are, indeed, well-known theoretical exceptions that are explained in the classroom that can cause the relation between the reduction of trade barriers and the increase in welfare to be non-monotonic. But they are not of great policy consequence. ${ }^{55}$

The approach to trade liberalization, enshrined in the GATT, is to bargain concessions on trade. There is 'first-difference' reciprocity: the reductions of barriers are generally mutual and 'balanced'. (Overall or full reciprocity - that is, balance of overall openness of one's markets - is presumably taken care of through setting an appropriate 'price' to GATT membership.) Such reciprocity of trade concessions is often considered 'mercantilist'; it suggests that trade liberalization is a cost rather than a benefit. But it makes sense in two ways. (i) If I liberalize and get you also to liberalize reciprocally, I benefit twice: I reduce my own barriers while I also improve my trading gains through the reduction of your barriers. ${ }^{56}$ (ii) There is also a 'second-best' argument when macro-economics does not work well. In this event, trade liberalization by oneself may lead to short-run adjustment costs, whereas simultaneous trade liberalization by others will reduce these costs. ${ }^{57}$

But the current approach of the United States to trade liberalization is altogether novel. It appears to demand that others (such as Japan) liberalize unilaterally (or else the crowbar will be used). How is this to be justified? As one reads the occasional justifications in different sources, a number of rationales can be discerned in an emotionally-charged debate.

Balance-of-Payments Arguments: A couple of arguments related to the payments situation can be distinguished:

(a) Japan has an enormous surplus in her trade balance and therefore she should liberalize her trade barriers faster than others. 
(b) The United States has an enormous trade deficit and therefore it is appropriate to ask others, who do not have a similar affliction, to liberalize their trade unilaterally.

These two arguments are related but still distinct. ${ }^{58}$ The latter, however, serves as the stepping stone to the former, which is the main driving force behind the pressures directed at Japan.

But this contention is not convincing because changes in trade barriers will not generally procure the sustained improvements in trade deficits which are desired unless a differential impact on the levels of savings and investment in the desired direction can be plausibly argued. In the absence of such impacts, the long-run effect of reduced foreign trade barriers will generally be to increase the trade-toGNP ratio at which the United States deficit will persist. ${ }^{59}$

There is a further 'systemic' objection to the argument. Suppose one wants to argue that freer world trade is a desirable goal, that it is (in the short run) easier for countries enjoying a large and persistent surplus to reduce trade barriers and that, consequently, such countries ought to take unilateral actions to liberalize trade without matching, mutual and reciprocal liberalization by others. If that is the case, one ought to work in the GATT, and in the IMF, to introduce such rules into the international institutions. Such rules could be built into revisions to the articles of the GATT that deal with balance-of-payments provisions (Article XII and Article XVIII) ${ }^{60}$ But to use this notion selectively against Japan and other targeted countries, through the unilateral exercise of power and without the corresponding assumption of a similar obligation when one's own deficit will turn into a surplus (as it surely will), is to sanction the view that it is fine for the big dog on the block to bark at - and also bite - the little dogs. The GATT properly assigns instead a symmetry of obligations and rights, establishing the rule of law rather than the law of the jungle.

The 'Japan-is-Cheating' Argument: What of the argument that Japan is cheating on the trade obligations which she assumed through the reduction of her trade barriers in successive GATT rounds during the post-war period? The negotiated cuts in Japan's trade barriers are not effective, it is said. Article XXIII, relating to impairment and nullification of obligations assumed by GATT members, is implicitly being invoked.

Japan, on this basis, can be asked to liberalize unilaterally. The demand, however, is not really for unilateral trade concessions. It is really a matter of returning to the true status quo as defined by obligations assumed earlier as part of the negotiated, reciprocal exchange of trade concessions.

The argument conjures up the image of the Japanese jackass refusing to move towards the carrot being offered. When you look behind him, you see the samurai holding him by the tail. One has to demonstrate, in short, that the effects of reduced trade barriers have been nullified and that this has been caused by governmental interventions aimed at securing such nullification. 
The econometric studies directed at the problem of whether Japan imports 'too little', either in aggregate or in manufactures, were motivated by this problem. If Japan is as open as she seems, how come her imports are so low? In particular, if Japan is significantly off the regression line on import shares, making her an outlier (in econometric jargon), then we can deduce that she is an out-and-out liar (in fulfilling her trade obligations). There are serious problems with this case against Japan.

1. As a recent paper by Koichi Hamada and T.N. Srinivasan argues, the econometric studies have been badly divided on the issue of Japan's import performance, but those which are better crafted and grounded in econometrically appropriate methodology ${ }^{61}$ do not support the view that it is unduly disappointing.

2. But even had the econometrics gone the other way, the results would not reveal that the hand of the Ministry of International Trade and Industry (MITI) in Tokyo was responsible for those results or that the cause was instead a host of other factors, including buyer preferences and institutional features which are conventionally, and for good reasons, treated as part of a country's 'givens' subject to which gains from trade are to be achieved in open markets.

The 'Japan-is-Different' Argument: In fact, it is interesting that Japan-bashing has now shifted increasingly away from the notion of the (malign) efficacy of the Japanese Government's invisible hand as the culprit and towards, instead, the inefficacy of Adam Smith's invisible hand as the source of trouble! Let me explain.

Economists take one's tastes as one's own affair. Given your tastes and mine, each sovereign in this regard, we can still engage in profitable, voluntary exchange. Economists do not argue, quite properly, that you must change your tastes to suit my convenience. ${ }^{62}$ That is the stuff of coercion and the politics of power. But that is precisely what some seem to want of Japan. They want her consumers and producers to change their tastes.

A recent Newsweek story typically reflected these sentiments when it reported on Japanese consumers. ${ }^{63}$

'[Japanese] consumers [do not] seem about to shed their bias against foreign goods. At one of INBIX's NIC stores recently, a 50-year-old salaryman looked at a CD player made in South Korea. The price was less than half of what he would pay anywhere else in Tokyo. He shrugged, then put it back. "No," he said. "I'm afraid it might break.",

The Newsweek reporters could have produced a more effective splash in the United States by repeating the story (no doubt apocryphal and born of the tensions produced by what is perceived as unfair Japan-bashing) where a Tokyo housewife walks into a Ginza store looking for a camera. Shown high-quality cameras, she asks: 'Don't you have something cheaper?' The answer: 'No. But just walk down the block. At the corner you will find a shop selling shoddy American stuff.'

But not all tastes, for or against imported goods, are 'irrational'. They can be grounded in reality more than is conceded by those who point accusing fingers. I 
recall writing nearly three decades ago from New Delhi to Harry Johnson on Indian stationery, complaining like V.S. Naipaul about the 'craze for foreign'. He came back with what could have a lesson for the American-Japan debate: 'If the quality of the paper you have written on is any indication, the craze seems quite sensible to me.'

The question of buyer preferences among Japanese firms for one another's goods is an even more explosive issue. It has received support recently from Mordechai Kreinin's study, reported in The World Economy, of 62 subsidiaries in Australia of Japanese, European and American companies examining the comparative way they procure equipment from sources outside Australia ${ }^{64}$

The issue is not whether such preferences exist. The issue is why. A large part of the buyer preference in Japanese businesses must relate to the value attached to customer relationships. That is an idea which is not merely sociological but is now incorporated as a possibly rational form of profit-maximizing behaviour in the modern theory of industrial organization. Even casual empiricism, based on one's exposure to American firms and products, whether autos or suits, shows that the philosophy underlying the American approach to consumers is caveat emptor, buyer beware. Dissatisfied or duped consumers must take recourse to litigation, aided by the largest legal establishment in the world; they are also supposed to vote with their feet where repeat-buying is involved.

The Japanese way is different. Their legal establishment is also correspondingly of a piece, small and lean, not large and mean. Consumer loyalty follows. It then becomes hard for American-style competitors to lure customers away by simply offering discounts that carry no assurance of follow-through and commitment to consumer satisfaction. Large enough discounts could overcome this problem. Everything has its price. But complaints of collusive Japanese preference for their own fill the air when discounts that are within reason but below those necessary lead to failure to find Japanese customers. It is not surprising that American firms that have made the necessary effort to adapt to Japanese ways have done well and are not among the vociferous complainants against 'autarkic' Japanese corporate buying preferences.

The buying preferences of Japanese consumers and firms are not grounds for demanding unilateral trade concessions from Japan. The appropriate attitude to the question of different Japanese preferences was conveyed by Paul Samuelson, who tells of encountering a charming old lady at a public lecture in Boston on trade policy. She went up to the Nobel Prize economist and said: 'Professor Samuelson, I would like to help by buying American, but the Japanese goods are so much better. Am I wrong in buying them instead?' Professor Samuelson answered, 'Madam, you should buy what you like. Leave it to us economists and the Congress to take care of the balance of payments.'

In any event, buying preferences are not areas which can be significantly influenced by policy. Yasuhiro Nakasone's appeals to the Japanese, when he was 
their Prime Minister, to 'buy American' are likely to have been as ineffective as, if more ludicrous than, those addressed by Americans to other Americans. Deterrent penalties and taxes by the government on those firms who do not buy American, or subsidies to those who do, are certainly policy instruments that could be deployed. But it is doubtful whether these can be seriously contemplated by a democratic government such as the Japanese any more than the United States Congress could enact a corresponding set of tax policies to penalize the consumption of American goods or subsidize the purchase of foreign ones. ${ }^{65}$

What, then, about the question of access to these buyers, no matter what their preferences? The retail distribution system in Japan, with its 1.6 million mon-andpop-style stores dotting the country and protected against large stores (recently by the passage in the Diet of the Large-scale Retail Store Law), militates against the distribution of foreign goods. ${ }^{66}$

This question is tricky. It needs careful handling at the level of general principles rather than immediate expediency. In particular, we need to ask here (and, indeed, similarly for other institutional issues) the following questions:

(a) Are these institutions designed to discriminate in favour of domestic goods and against foreign rivals?

(b) If their unintended fall-out is to affect trade directly, can we think of 'next-best' ways in which such effects can be minimized.

(c) In seeking such relief, can we think not just of others accommodating to our needs but of establishing general disciplines, and neutral procedures to settle disputes relating thereto, to which we subject ourselves as much as we seek to subject others?

In the case of the Japanese distribution system, the answer to question ' $a$ ' is surely, 'No'. The answer to question ' $b$ ' is that it does inhibit, although it does not prevent, access for firms that prefer marketing products through large outlets, but that these firms could adapt their sales techniques with possibilities such as mail-order selling, which has begun and offers a possible way out. As for question ' $c$ ', if national distribution systems are to be considered legitimate grounds for foreign scrutiny, the United States should propose procedures under which it becomes possible for other trading countries generally to challenge its own distributive institutions and methods as well. ${ }^{67}$ An advantage of such general procedures, applying symmetrically, is that it would slow down the one-way demands for others to 'reform' which are otherwise readily generated by lobbies in the United States. The argument by the Administration that one's excesses can come home to roost has traditionally helped to contain such excesses. There is no reason to expect that it would fail to do so in this area.

It is necessary to observe that the path down which the United States is currently going in its negotiations with Japan under the rubric of the Structural Impediments Initiative, where matters such as Japan's retail distribution system and even her 'high' savings rate are being discussed as obstacles to trade, is the path of folly. 
This is so not merely because it proceeds on a one-on-one basis without the benefit of general procedures uniformly applying to all. It is also because, once one starts bringing into the trade arena issues such as rates of savings, one is essentially arguing that everything affects trade, that policy (or absence thereof) on virtually everything will affect trade and, accordingly, every policy can be put on the line in discussing what is 'fair trade' and a prerequisite for legitimate free trade.

Thus if Bangladesh currently has a comparative advantage in textiles, due to lower wages, we no longer need to worry about being scolded as protectionists when we reject imports of Bangladeshi textiles as unfair trade caused by her 'pauper labour'. After all, the low Bangladeshi wages are a result of inadequate population-control policies and, too, of inefficient economic policies that inhibit investment and growth and thus a rise in real wages. Or, if the United States continues to produce textiles which rely heavily on immigrant labour, often illegal, this is unfair trade because American immigration policy encourages this outcome and, therefore, a demand for changes in immigration policy needs to be made against the United States simply to ensure a level playing field.

In going down this unwise trade route, the American makers of trade policy have put the world trading system at great risk. If everything becomes a question of fair trade, the only outcome will be to remove altogether the possibility of ever agreeing to a rule-based trading system. 'Managed trade' would then be the outcome, with bureaucrats allocating trade according to what domestic lobbying pressures and foreign political muscle dictate.

Unfortunately, this danger is not seen by many in the United States who, in the current psychology attending the 'diminished giant' syndrome, fail to look at the long-run and systemic implications of what they propose as short-term policy options for the United States.

The Divergence between Ex Ante and Ex Post Outcomes: Yet another reason for making demands for unilateral trade concessions by others can be detected. It is based on the notions of Japan's anti-foreign-goods biases, 'natural' and institutional, but uses them in an altogether different way.

The argument is that when Japan's cuts in trade barriers were accepted during earlier GATT rounds as 'equivalent', 'matching' or 'balanced' relative to American cuts, the negotiators for the United States over-estimated the extent to which Japanese imports would rise - given Japan's buying preferences and institutions. But, as we now know, these forces are of such importance that what Japan gave was far below what America gave. The ex post realities show that the trade in concessions was unbalanced, thus giving the United States the moral, perhaps even the legal, right to 'reopen the issue' and ask for unilateral concessions from Japan.

This notion that 'first-difference' reciprocity be negotiated (inevitably) on ex ante perceptions of mutual advantages while it can be renegotiated on the basis of ex post outcomes is certainly present in some of the sentiments for unilateralism in 
American demands for others to move towards new trade concessions without reciprocal concessions by the United States. Edmund Dell, Secretary of State for Trade in the British Government in 1976-78, writes cogently on the subject:

'There has been a feeling in the United States that in many cases, whatever the intention or skill of American negotiators, reciprocity has not been achieved. Some of its trading partners have been found to have had the better of the bargain. This is particularly seen to be the case in the trade relations of the United States with Japan. . . Robert Dole, now majority leader in the United States Senate, [has argued] that "reciprocity should be assessed not by what agreements promise but by actual results - by changes in the balance of trade and investment between ourselves and our major economic partners". There is pressure, therefore, to the effect that the United States should withdraw something of what it has conceded - especially, although not entirely, in its relations with Japan. ${ }^{68}$

More importantly, the sentiment and the pressure translate into unilateral demands for unmatched concessions by Japan, in particular. But there are several things to be said about this sentiment.

1. In terms of GATT law, is the 'reopening' of negotiated concessions in this fashion permissible? Article XXIII relates to impairment and nullification of negotiated GATT agreements. Whether this would extend to alleged ex post outcomes that depart from expected outcomes is highly dubious. There certainly do not seem to be any precedents in dispute settlements under Article XXIII that would provide ammunition to the General Counsel to the United States Trade Representative, should the latter take up the matter for an authoritative ruling on the subject.

2. The reopening of contractual commitments is generally considered destructive of orderly trade and intercourse, with exceptions permitted only when the contract was signed under duress or when the doctrine of 'intervening impossibility' can be invoked - both exemptions usually requiring a heavy burden of proof by those who seek relief. If the United States were to argue for nullification of its trade obligations towards Japan, it seems improbable that it could win, with legitimacy, on either of the two grounds mentioned.

3. Moreover, just imagine what would happen to the trading system if ex post outcomes, themselves reflecting a host of factors which cannot possibly be isolated and quantified persuasively, were to be used to renege on trade concessions or to demand more from others after deals had been struck at trade negotiations.

The 'Imbalance-from-Shift-in-Comparative-Advantage' Argument: A different argument for unilateral liberalization because of ex post realities diverging from ex ante expectations can be traced to the feeling that shifts in comparative advantage have created an imbalance of mutual advantages from earlier trade concessions. 
American policy makers, persuaded by lobbies and by independent evidence, feel that American comparative advantage has shifted in favour of agriculture and services. These are the sectors that are subjected to high trade barriers and to the failure of GATT disciplines. ${ }^{69}$ In consequence, the same structure of trade barriers produces now, in the American view, a lower average barrier in the markets of the United States for others than for the United States in the markets of others.

Therefore, although the initial reductions of barriers were balanced, they cannot be regarded as such anymore. The United States is accordingly justified in asking for changes in trade barriers in these sectors simply to restore the balance of negotiated advantages. While, of course, the United States is willing to have mutual reductions in trade barriers in these new sectors, the fact that they are of principal export benefit to itself means that they amount to an unbalanced trade concession going its way.

The 'Coming-of-Age' Argument: An argument which applies not to Japan but to other countries of the Far East (and potentially to other newly industrializing countries which are successful exporters) is that they have had a free lunch so far, having been afforded special-and-differential treatment in GATT negotiations, thanks to which they could use tariffs and other trade barriers but profited from the general reductions in the trade barriers of developed countries in the post-war period because of unconditional MFN treatment. In terms of 'first-difference' reciprocity, these countries secured unbalanced trade concessions in their favour, making overall access to their markets significantly less than their access to the markets of the developed countries. For those countries, such as South Korea and Taiwan, which have come of age in terms of both exports and per capita incomes, this 'affirmative action' is no longer justified. They must now assume their full obligations as GATT members, as the developed countries do. This means that they must unilaterally lower trade barriers or, what is the same thing, provide greater concessions in future negotiations than they get.

Within the logic of reciprocity, the argument is well taken. Special-anddifferential treatment for the developing countries was never granted by other GATT members as a permanent 'benefit', simply because the GATT is premised on the assumption of symmetric rights and obligations and on 'first-difference' reciprocity as a method of negotiation to reduce barriers and, for that reason, any exemption from the symmetric obligations has to be legitimated. For developing countries, this legitimacy was provided by infant-industry and balance-ofpayments arguments (as reflected in Article XVIII). But the developmental status of some developing countries has changed; and the theoretical support for exempting any of them from the obligations of open market access on grounds such as balance-of-payments difficulties has also waned. ${ }^{70}$ On both grounds, the 'coming-of-age' argument for seeking unilateral concessions from South Korea and Taiwan has acquired cogency. 
The 'I-am-More-Open-Than-Thou' Argument: Finally, there is in many quarters the firm belief that the United States is more open than other countries, not just the developing ones. This also helps to fuel demands for unilateral trade concessions by others, especially when combined with another belief that immediately after World War II and in the 1950s and 60s the United States was altruistic in trade policy, but, in its age of relative decline, must now rejoin the human race and 'look after its own interests'.

But evidence on the trade barriers of the United States, particularly after the proliferation of high-track as well as low-track protection in the 1980 s, certainly does not provide support for the view that it is now significantly more open than other developed countries. ${ }^{11}$

This is hard to believe because the United States, formed by immigration, is far more 'open' in its cultural attitudes and willingness to experiment with foreign ideas, foreign influences and foreign goods than most other countries, most of all Japan. But culture does not necessarily translate into corresponding trade policy. The latter reflects equally the play of politics and economic forces. There is in consequence nothing inconsistent, although much that is incongruous, about a culturally-open society having access to its markets as restricted by trade policy as a country (such as Japan) which is more inward looking in its citizens' attitudes.

Again, the culturalists find it difficult to believe that protectionism can coexist with a deficit in the balance of trade. Thus James Fallows has recently written: 'Japanese and Korean politicians now complain about American "protectionism", but how protectionist can a country with a $\$ 10$ billion monthly trade deficit really be?' 2 Mr Fallows, whose initial wisdom on America's 'Japan fixation' has unfortunately yielded to exaggerated pessimism and folly in later writings, is remiss here. Any given degree of protectionism is generally compatible with any level of trade surplus or deficit.

Perhaps the only countervailing argument in support of the presumption that the United States is more open is that it is most open in regard to receiving foreign investment and that this can give foreign suppliers in some cases more effective access to the American market. ${ }^{73}$ This asymmetry certainly applies to Japan and is an argument for pressing Japan for greater mutuality of openness in the matter of foreign investment.

As for the view that the United States acted altruistically - that is, as a unilateral free trader of sorts - during the post-war period, this too can be exaggerated. It is useful to remember that, unlike Britain through most of the nineteenth century, the United States has never been a unilateral free trader, generally insisting on reciprocity in trade concessions - as signified by the Reciprocal Trade Agreements Act of 1934 and later by the contractarian conception of the GATT. Do not forget either that the first agricultural waiver from GATT discipline was secured by the United States in 1955, effectively leading to the chaotic situation in agriculture today. The United States was also among the 
earliest countries to start restricting textile imports, initiating the descent down the road to the Multi-fibre Arrangement (MFA) that restricts and regulates exports of textiles and clothing from developing to developed countries.

These matters need a reminder, not to deny the justly celebrated leadership of the United States (as distinct from altruism) in the conduct of trade policy and in promoting the concerted reduction of tariff barriers through successive GATT rounds, but simply to prevent exaggerated notions of past altruism leading to current policies of system-destroying selfishness.

It is perhaps worth remarking that the theme of America's greater openness can be used selectively and has not deterred similar pressures being exercised against countries for trade concessions even when they are unambiguously more open than the United States. While America's greater openness vis-à-vis Japan is open to doubt, Hong Kong's greater openness vis-à-vis America is not. In fact, Hong Kong, aside from nineteenth-century Britain, is a textbook example of (substantially) free trade. Yet the high-handedness of the United States in dealing with its legal services industry was a matter of public dispute in early 1989 as the legal profession of Hong Kong was threatened by punitive tariff retaliation for the colony unless it opened up Hong Kong to American lawyers. ${ }^{74}$ In short, the assumed greater openness of the United States has served as a way of demanding unilateral trade concessions from others, used where it can be made without obvious implausibility and discarded when it plays the wrong way.

THE CROWBAR: SECTION 301 AND SUPER 301

These arguments for unilateral trade concessions by others, many of them not compelling on detailed scrutiny, but all of political potency, together with the growth of interests that were sketched earlier, made it inevitable that the trade policy of the United States would move in the direction of Section 301 and Super 301 with the Trade Act of 1988 . Such one-way demands cannot be satisfied with the conventional techniques and within the framework of the GATT. In the GATT framework, trade concessions can be found only by offering one's own. By contrast, unilateral concessions must be extracted, not by gentle negotiations but by threat.

Moreover, export interests are evidently at a disadvantage in the GATT framework where trade concessions by others are available on a non-discriminatory basis to all GATT members and hence give one no privileged access in the new markets, whereas trade concessions can be captured to one's preferential advantage through 'voluntary import expansions' (VIEs) and trade diversions towards themselves when the concessions are obtained instead in a one-on-one bilateral framework. ${ }^{75}$ Section 301 , originally enacted in 1974, but suitably endowed with sharper claws in the $1988 \mathrm{Act}$, is a policy instrument that can serve 
these ends, amounting therefore to what can be fairly described as 'export protectionism'. ${ }^{76}$

But there are two other, partly inter-related, factors that must also be cited as having led to the rise of Section 301 to its prominent role in policy-making.

First, the panic identified earlier over the trade deficit and over possible de-industrialization certainly produced a sense of crisis which created, in turn, the sense that urgent action was needed to prevent America's continuing ruination. Even if the many arguments for extracting something for nothing in trade had not been seen to be legitimate, the impatience for quick results on the trade front would have imperilled the commitment to multilateralism under the GATT. Given the United States' indisputable (even if diminished) strength and new willingness to wield a crowbar and thus use its muscle, it could certainly go faster, even in getting others to make balanced and mutual (rather than unilateral) concessions in matters that it considered essential to its trade interests, if it used one-on-one techniques. In place of the GATT, sometimes (naively) denounced as the General Agreement to Talk and Talk, the Section-301 procedures could guarantee the quicker attention and response that was considered urgently necessary.

Second, there was also the more benign view that one-on-one techniques were complementary to, rather than substitutes for, GATT-centred multilateralism. They would, by ruffling feathers and demonstrating American resolve, bring other countries to the bargaining table at the GATT on agricultural trade and on the 'new issues' of trade in services, trade-related investment measures (TRIMs) and trade aspects of the protection of intellectual property rights (TRIPs) ${ }^{77}$ when others had been dragging their feet.

For both these arguments the underlying common denominator is the sense of urgency and consequent impatience. But the payments deficit driving the impatience has little demonstrated relationship to results on trade policy. It is a non sequitur to translate urgency on the trade deficit into urgency on getting results in the conduct of trade policy.

Nor can it be seriously maintained that the type of unilateralism characterized by Section 301 was necessary to get the Uruguay Round negotiations going. Admittedly, the European Community's refusal to support the launch of multilateral trade negotiations, as desired by the United States, at the special GATT ministerial meeting of November 1982 was a major blow to American efforts to get new disciplines negotiated multilaterally. But three factors, other than the new Super-301 provisions (enacted less than two years after the Uruguay Round negotiations were launched), were responsible for the Community turning around:

(a) There was a growing realization by the Community, not present in 1982, that on the new issues of trade in services, TRIMs and TRIPs its member countries would benefit as well as the United States, so that they also had much to gain from a new GATT round. 
(b) The free trade proposal with Canada suggested that the United States would embrace regionalism more extensively as a substitute for GATT-wide multilateralism, extending this approach also to the new issues, if the other trading countries did not agree to a new GATT round.

(c) And the mood in the United States Congress, as often before earlier GATT rounds, was protectionist and ugly enough to make it seem necessary for other countries to begin multilateral trade negotiations to help the United States Administration resist protectionist pressures. ${ }^{78}$

There is very little to suggest that Section 301 was necessary or was instrumental in any way in getting the Uruguay Round negotiations launched.

Unfortunately the Section-301 instrument has many difficulties inherent in it and corresponding possibilities of damage to the world trading system. Some difficulties are bad enough. Others are serious.

When the United States confronts the strong, such as the European Community, with Section-301 actions, it is likely to provoke strongly spirited reactions - as in fact happened with the Section-301 action which led to the dispute over trade in hormone-fed beef. While such disputes will settle, with cataclysms such as generalized 'trade wars' highly improbable, the battle still leaves scars. The ethos spreads that the trading system is unfair. Xenophobia can strengthen. Protectionists can only find this to their advantage as they continually seek to manoeuvre the legislative and administrative processes to obtain protection.

When the United States confronts the weak, the latter are likely to buckle under, as South Korea did on insurance earlier and on the Super-301 threats she escaped on 25 May 1989. But the danger now is that the smaller countries which the United States confronts in trade will view the Super-301 actions as the way of the bully, reviving the image of the 'ugly American', leading gratuitously to anti-Americanism.

But, even if American policy makers were unmindful of these consequences, there is a strong likelihood that the targets of their Section-301 actions will satisfy American demands by diverting trade from other countries (with smaller political clout) to the United States, satisfying the strong at the expense of the weak. ${ }^{79}$ America does not open markets efficiently this way. She diverts trade. While this serves the interests of the United States and its exporters, it replaces economic efficiency with political clout as the determinant of trade.

This danger has been recognized by the United States Trade Representative. Ambassador Hills now repeatedly stresses how she will ensure that markets are opened under Super 301 in a non-discriminatory fashion. But ex ante intentions can diverge from ex post outcomes. The lobbies in the United States that influence the USTR do not really care whether markets open generally; their objective is to secure market access for themselves and their general thrust is to judge openness in terms of their own success. Equally the countries targeted for action know that the American pressures are therefore more likely to ease if the 
United States gets a good share than if it does not. The game is set up in terms of implicit pro-trade-diversion-bias rules that all parties recognize as political realities.

Then again there is the problem with the actual use of the crowbar. It is not merely unwise. It has also been occasionally GATT illegal.

The GATT has the legal force of a treaty in the United States ${ }^{80}$ GATT illegality therefore violates a treaty commitment. The feeling that the GATT can be disregarded ('Who cares about the GATT?') because 'we never ratified it' is widespread but unjustified. Consequently the United States is not free to retaliate at will by raising tariffs on goods. It has nonetheless done so in the cases of Brazilian informatics, beef from the European Community and arguably Japanese semi-conductors. In this regard, it was not surprising that at the GATT Council meeting in January 1989, 51 member countries joined in invoking Article XXIII in protest against the American violation of GATT obligations; and the Super-301 actions of 25 May 1989 (which offer the prospect of ultimate GATT-illegal retaliation if they are to be effective) have drawn virtually unanimous condemnation from other trading countries.

The United States therefore stands in the dock accused of violating (or threatening to violate) GATT rules. This brings into disrepute the Administration's efforts in the Uruguay Round negotiations to strengthen the GATT trading system by putting the United States in what foreign countries see as an inconsistent position via-à-vis the GATT.

Even if one were to disregard GATT illegality, on the (not persuasive) ground that some 'creative illegality' was necessary to get GATT member countries to agree to a new GATT round, the essential drawback to Super 301, as currently designed, is that it does not impose on the United States the same disciplines, and the same procedures to establish them and settle disputes under them, as it imposes by threat on others. It is thus built on the asymmetry of power which serves the United States interests because it is the more powerful vis-à-vis most targets. But this is not the way of a properly functioning international trade order in which rights and obligations are symmetrical. The GATT was correctly built on the conception of the rule of law where obligations apply reasonably uniformly to all. ${ }^{81}$

In view of the serious drawbacks of the Super-301 instrument, how does one cope with it? The Super-301 actions on 25 May 1989 suggest that, given the strength of Congressional sentiments, the Bush Administration is unwilling to expend political goodwill to stop the folly of its use when 'push comes to shove' ${ }^{82}$ It cannot be eliminated by new legislation: the United States Congress is the problem, not the solution. The only way out is to defang the monster. Bearing in mind that Super 301 cannot work unless the threat of retaliation is credible, and that such retaliation would be almost certainly GATT illegal, the targeted countries should raise the matter formally in the GATT (whenever retaliation is 
undertaken). ${ }^{83} \mathrm{~A}$ finding that Super-301 retaliatory actions would be GATT illegal would then put the matter squarely into President Bush's lap. He must either violate the treaty obligations of the GATT or exercise the discretion built into the 1988 Act and say 'No' to the protagonists of Super-301 actions. I imagine he would choose the latter option. ${ }^{84}$

\section{FIX-QUANTITY TRADING REGIMES OR MANAGED TRADE}

While the analysis of the demerits of the Super-301 approach to prying open foreign markets, and of its intimate relationship with export interests and the ethos legitimizing the seeking of unilateral trade concessions by others, requires sophisticated reasoning, the demerits of managed trade are more egregious and obvious to economists.

The proponents of managed trade seek to define targets of 'appropriate' exports in specific industries to foreign countries with commitments by those countries to fulfil the targets. ${ }^{85}$ While these targets can relate to total imports, or to total imports from the United States, they are typically more narrowly defined as specific quantitative targets for specific imports from the United States. An example is the American pact with Japan on trade in semi-conductors, recording the demand for a 20 per cent American share in the Japanese market.

The 1980s have seen a proliferation of such 'fix-quantity' trade arrangements in regard to one's imports: 'voluntary' export restraints (VERs) on autos and steel are a typical example. If the managed-trade proponents had their way, there would be 'voluntary import expansions' for one's exports to match these VERs for one's imports.

These demands derive from some of the same conceptions about Japan that drive the demands for unilateral trade concessions by her: in particular, that her policies, preferences and institutions make Japan hard to penetrate. Therefore, quantitative commitments by Japan to import specific quantities of particular goods from the United States, in whatever way the Japanese do so, are deemed necessary.

This would mean the replacement of the fix-rule approach to trade, as built into the GATT, by a fix-quantity trade regime. We would be replacing the rule of law that the GATT embodies, where trading countries compete subject to common rules, by a system where politics and bureaucrats would essentially determine trade quantities. Before this retrograde step is taken, the case for it must be examined, for it is exceptionally flawed.

For one thing, the notion that Japan's policies, preferences and institutions make it hard, even impossible, to sell to her people is unsupported by the facts. Not merely is it impossible to support econometrically, with any confidence, the contention that Japan imports too little. But, at the margin as well, there is enough 
evidence to show that Japan's imports respond to price changes, such as the rise of the yen and the fall of the dollar, much the way other countries' imports do. ${ }^{86}$ Despite their many cultural differences, known to anyone who has read the great novelist Junichiro Tanizaki's beautiful essay In Praise of Shadows, the Japanese belong to the same human race that Adam Smith wrote about.

It is not meaningful to ask countries to ensure target quantities of specific imports. They can restrain exports by enforcement. But how are they to ensure imports by their consumers unless the state is the buyer? Subsidies by the United States could be an instrument to encourage more purchases; but how would the United States reconcile this with its general position in the GATT and in national practice against subsidization? Indeed, the United States imposes countervailing duties against subsidies by foreign rivals.

There is also the oft-repeated claim that the targets to be set and enforced for imports of specific items from the United States by Japan will reflect the 'fair' and 'appropriate' share of the Americans in the Japanese market. But this is not sensible.

There is no sufficiently unambiguous and plausible way in which such fair shares can be estimated in general. Third-market shares of the United States and Japan are often cited by some to argue that Americans ought to enjoy similar shares in Japan herself. These third-market shares, however, will reflect relative expenditures by Americans and Japanese in cultivating these markets, the differential incidence of protection against Japanese exports in third markets (for example, the European Community has conducted a 'Fortress Europe' policy against Japan throughout the 1980s), the value attached by these markets to different product characteristics and a host of other factors that do not carry over mechanically into the Japanese market. ${ }^{87}$ Besides, if Americans were to apply this approach to estimating how much they deny a fair share of their market for each traded product to other trading countries, they would be unpleasantly surprised, I am sure, at the 'findings' of their own hidden barriers against imports of specific items from specific countries.

These objections apply also to the less restrictive versions of managed trade. The demand that Japan import specific quantities without specifying sources is better. But it is no more feasible and desirable than the demand for source-specific increases in imports by Japan. Nor is the version that Japan increase her total imports, or total imports of manufactures, by a target figure or be penalized. ${ }^{88}$

To proceed down the road to managed trade, despite its popularity with the export lobbies, its appeal on Capitol Hill and its advocacy by some, would just be another act of folly. ${ }^{89}$

\section{REGIONALISM}

While, then, the turn to unilateralism and the pressures to embrace managed trade are matters which economists can reasonably agree to consider detrimental, 
and even perilous, to the world trading system, the issue of regionalism is a matter where they can reasonably disagree.

In theory, economists have long known that preferential trading arrangements can always be devised between any group of countries so that they are welfareimproving for those who undertake them and do not harm those who are outside. ${ }^{90}$ By the conventional criteria for evaluating policies, such preferential arrangements would be considered desirable.

The relevant question is whether the specific arrangements, such as the European Community or the United States-Canada Free Trade Agreement, meet these conditions. This question was seriously discussed in the 1960s when the Community was formed and when all kinds of regional arrangements such as EFTA, LAFTA, PAFTA and NAFTA ${ }^{91}$ were being pursued or contemplated in different regions around the world in an early 'play' of what many think ahistorically is a novel trend today, two decades later (after the first trend died despite a similar show of apparent strength).

Interestingly, this kind of question has hardly been posed in recent discussions of the United States-Israel Free Trade Agreement and the United States-Canada one, at least at the time of the intense political debate that surrounded the latter. In short, one cannot find any parallel degree of scepticism and interest in the United States Congress or in academic analyses concerning the question whether the United States-Canada Free Trade Agreement would lead to trade diversion and, if so, sufficiently to reduce rather than increase welfare for the United States, its partners and the world. ${ }^{92}$

The reason lies, it seems, in the virtue seen in the mere fact that the CanadianAmerican agreement represented, to the public eye, a dramatic pro-trade measure that would take the political momentum away from the protectionists. Trade diversion was no more a worry for policy makers here than it would be for those who ignored the likelihood of producing VIEs rather than multilaterally open foreign markets when undertaking Super-301 actions.

Virtue was also found in the fact that, as part of the Canadian-American agreement, progress was made in negotiating trade in services. This, too, was seen as imparting momentum, not merely by example but also by implied threat (that the United States, if necessary, would move ahead with 'like-minded' countries on services if the GATT talks failed), to the progress of the talks on trade in services in the Uruguay Round negotiations.

An undisputed merit of the United States-Canada Free Trade Agreement has again been the inclusion, on Canadian initiative and insistence, of a bi-national procedure for reviewing national 'unfair trade' adjudications. In a world where countries increasingly make charges of unfair trade at one another, the oldfashioned ways of doing business in these matters are getting rapidly obsolete. The traditional way, where (say) Americans complain, and American institutions judge, much like Judge Dee of medieval China who acted as the prosecutor and the 
judge, makes little sense in today's world. Increasingly, we need to settle such complaints by neutral, impartial procedures, like those of the GATT. The Canadian-American agreement made a real contribution in that direction, paving the way for future models of institutional change designed to handle better and contain the damage from the increased obsessions with unfair trade.

The problem, however, is that these benefits must be balanced against the costs. The major cost comes from an unanticipated fall-out of the United States-Canada Free Trade Agreement. The coincidence of the Canadian-American agreement and 'Europe 1992' was fortuitous. Europe 1992 was prompted by the wholly different goal of making the common market commoner, taking the last, difficult, almost insuperable, steps towards the political and economic unification that the Treaty of Rome had adopted as its objective. But the coincidence of these two dramatic events, plus the jaundiced view of the GATT on Capitol Hill and the indifference to the GATT illegality of the actions contemplated under the Super-301 provisions of the Trade Act of 1988, suggested to many abroad that, despite professions to the contrary from the Administration and its efforts at the Uruguay Round negotiations, the American commitment to multilateralism had ended. Regionalism had arrived. The world was fragmenting into trading blocs.

Unfortunately, this inference of a trend from two observations can be selffulfilling. It has tended to produce a sense in the Far East, for instance, that a Japan-centred regional bloc in the Asian-Pacific region may be necessary in a bloc-infested world. The effect would surely be to undermine the energies spent on making the Uruguay Round negotiations successful, with its vast and difficult agenda of remaking the GATT to suit the needs of the modern world.

In my view, it is absolutely imperative for the United States to reject the temptation therefore to move towards further such regional arrangements, eschewing the suggestions to strike special deals with Mexico and others, so as to convey a clear message that the Canadian-American free trade area was a special event, much like European unification, with Europe 1992 as its culmination. ${ }^{93}$ Here lies the greater wisdom, if less immediate profit. ${ }^{94}$

\section{CONCLUDING OBSERVATIONS}

United States trade policy presents a confusing picture today, even a disturbing one. It is conceivable that the trends towards unilateralism and regionalism will fade away. Nothing in economics is predictable with certainty. But if the analysis presented here is accurate, many of the underlying causes of these trends are fundamental and, therefore, they are unlikely to vanish in the immediate future.

The pessimistic scenario is that the United States will find itself unable to play the role of an energetic supporter of GATT-based multilateralism, being constrained by the powerful forces working through the Congress. One may fear 
equally that, unless the Administration manages to persuade the Congress that the extension of multilateral disciplines to complex new areas such as trade in services has necessarily to be a continuous and slow process, not to be judged in terms of immediate quick-fixes and 'results', the Congressional embrace of unilateralism and regionalism will intensify after the Uruguay Round negotiations are concluded at the end of 1990 and weaken further the capacity of the Administration to strengthen and revitalize a GATT-focused multilateral trading regime.

At the same time, the newly emerging power, Japan, will not be able to play a major role either in that direction, much as it is also in her own interest, simply because she has never played the role before, having only recently acquired her economic sinews. There may then be a leadership vacuum, with the GATT and multilateralism falling through the cracks during this transition.

The optimistic scenario, on the other hand, is that a clear delineation of these dangers, sharply sketched, will alert the United States Administration to the impending dangers and spur it into making the effort, both in Washington and in Geneva, to save the multilateral trading system which has served the United States and the world economy so well in the post-World War II period.

1. This article is based on a paper delivered at a conference on United States Trade Policy at Columbia University, New York, on 8 September 1989, sponsored by the Department of Economics and the Program on Journalism and International Economics, financed by the Sloan and Ford foundations respectively. In writing the paper, I have profited from the human capital of many. The writings of Michael Aho, Robert Baldwin, Michael Finger. Robert Hudec, Douglas Irwin, Robert Lawrence, Gary Saxonhouse and Martin Wolf have been particularly helpful. Thanks are due to Claude Barfield Jr, Richard Clarida, Paul Samuelson, T.N. Srinivasan and Lawrence Summers for helpful comments.

2. For a detailed discussion of these developments, see Jagdish Bhagwati, Protectionism (Cambridge, Massachusetts: MIT Press, 1988) ch. 4. Also, see the excellent review article by David Palmeter, 'The Capture of the Antidumping Law', Yale Journal of International Law, New Haven, No. 14, 1989, pp. 182-98.

3. The verbal commitment to multilateralism remains high in Washington. But the actual developments are not so sanguine.

4. See Robert E. Baldwin, 'United States Trade Policy, 1945-1988: from Foreign Policy to Domestic Policy', mimeograph, Department of Economics, University of Wisconsin, Madison, 1989 , for an insightful analysis documenting this.

5. (i) The Caribbean Initiative and recent bilateral arrangements with Mexico are other, relatively minor, examples of the new willingness in United States trade policy to work with less-than-multilateral (that is, less than GATT-membership-wide) trade arrangements. (ii) On a related front, the United States has also adhered to the view that the GATT codes negotiated in the Tokyo Round deliberations established conditional, rather than unconditional, MFN rights for signatory countries. (iii) Again, the United States negotiating position in the Uruguay Round negotiations on services has been reported to involve going, if necessary, with 'like-minded' countries and not extending the benefits on an unconditional MFN basis to the non-signatory developing countries.

6. Cf. Lester C. Thurow, 'GATT is Dead', speech to the Davos Symposium, World Economic Forum, January 1989, mimeograph, obtainable from the Sloan School of Management, Massachusetts Institute of Technology. 
7. For a lucid and authoritative clarification of the relationship of Section 301 under earlier legislation and the 1988 Trade Act, see Judith Bello and Alan Holmer, 'The Heart of the 1988 Trade Act: a Legislative History of the Amendments to Section 301', Stanford Journal of International Law, Fall 1988, pp. 1-44; and 'Unilateral Action to Open Foreign Markets: the Mechanics of Retaliation Exercises', The International Lawyer, Chicago, Winter 1988, pp. 1197-206.

8. The semi-conductor pact fitted the bill precisely in this way: 20 per cent of the Japanese market to be set aside for United States semi-conductors. While there was ambiguity about whether 20 per cent was a target or a 'guideline', the United States showed no hesitation in treating it as a target when undertaking retaliation for non-compliance.

9. I insert the adjective 'import' not because of unfamiliarity with the rule of redundancy, but deliberately. Later I argue that pressures for 'export protectionism' have appeared on the United States scene, accounting for some of the disturbing shifts in United States trade policy.

10. Adjusting for the vastly increased demands for protection, the Reagan Administration may be defended as having 'supplied' no more protection than its predecessor under President Carter. But the increased 'demands' for protection were partly a consequence of the Administration's own macro-economic policies.

11. Michael Gavin has alerted me to remind the reader that devaluations may affect excess spending as when they successfully switch expenditure towards home goods in a situation of Keynesian unemployment or, secondly, as when the rise in import prices increases real saving due to the wealth effect, as in the celebrated Laursen-Metzler-Harberger analysis. The former model is not valid currently; the latter effect could not be important. Also see Note 16 below.

12. The chief proponents have been Richard Baldwin, 'Hysteresis in Import Prices: the Beachhead Effect', American Economic Review, No. 4, 1988, pp. 773-85; and Richard Baldwin and Paul Krugman, Persistent Trade Effects of Large Exchange Rate Shocks, NBER Working Paper No. 2017 (Cambridge, Massachusetts: National Bureau of Economic Research, 1986).

13. This is evident from a report by Robert Kuttner (of a conference of the leading figures in international macro-economics in late 1987), 'The Theory Gap on the Trade Gap', New York Times, 17 January 1988, Section 3, p. 1, where the presence of trade barriers as an explanation of the failure of the pass-through effect is not mentioned. This omission is also in the early studies, including Catherine Mann, 'Prices, Profits, Margins and Exchange Rates', Federal Reserve Bulletin, Washington, June 1986, pp. 366-79, and Krugman, Exchange Rate Instability (Cambridge, Massachusetts: MIT Press, 1989).

14. This hypothesis is discussed at length in Bhagwati, 'The Pass-through Puzzle: the Missing Prince from Hamlet', mimeograph, Department of Economics, Columbia University, New York, December 1988. The paper was summarized in an Economics Focus column, 'Passing the Buck', The Economist, London, 11 February 1989, p. 63.

15. In particular, the experience of the automobile industry bears out this hypothesis. See Kiyohiko Shibayama, Michiko Kiji, Toshihiro Horiuchi and Kazuharu Kiyono, Market Structure and Export Prices, Discussion Paper No. 88-DF-1 (Tokyo: Research Institute of International Trade and Industry, Ministry of International Trade and Industry, 1988). The impact of the trigger-price mechanism on United States steel imports on the pass-through effect is also borne out. As Dr Shibayama communicated to me: 'On the aggregate level, pass-through ratios for Japanese exports have been lower during this post-1985 period than during the 1977-78 period of the high yen. More than half of this decline may be attributed to a decrease in the pass-through ratios for Japanese steel and automobiles, two of our country's principal exports.' (Letter dated 14 February 1989.)

16. For careful analysis of this question, see W.M. Corden, 'Trade Policy and Macroeconomic Balance in the World Economy', forthcoming in Charles Pearson and James Riedel (eds), Essays in Honor of Isaiah Frank (Baltimore: Johns Hopkins Press, 1990). Also see Richard H. Clarida, 'That Trade Deficit, Protectionism and Policy Coordination', in this number of The World Economy.

17. Some economic studies show that United States protection will improve the trade deficit. But these results come from assumptions - for instance, that the revenues from the tariffs are saved. The implied notion that the United States has become sufficiently under-developed to need revenues from tariffs, as many poor countries used to do, would be amusing if it were not so damaging to sensible 
policy-making. See Rudiger Dornbusch, 'External Balance Correction: Depreciation or Protection?', Brookings Papers on Economic Activity, Washington, No. 1, 1987, pp. 249-69.

18. See Bhagwati, Protectionism, op. cit.

19. Cf. Bhagwati, 'A Giant among Liliputians: Japan's Long-run Trade Problem', in Ryuzo Sato and Julianne Nelson (eds), Beyond Trade Friction: Japan-United States Economic Relations (Cambridge: Cambridge University Press, 1989).

20. Sol Chaikin, 'Trade, Investment and Deindustrialization: Myth and Reality', Foreign Affairs, New York, Spring 1982, p. 848. Other telling examples are quoted in Bhagwati, Protectionism, op. cit., pp. 99-101.

21. The foremost members of the de-industrialization school in the United States are Stephen Cohen and John Zysman, Manufacturing Matters: the Myth of the Post-industrial Economy (New York: Basic Books, 1987). While the British school has virtually become defunct, after an initial splash and having had a temporary impact on British legislation in the form of a Selective Employment Tax designed to create differential incentives for employment in manufacturing at the expense of services (see Bhagwati, Protectionism, op. cit., ch. 5), the American school has recently gained a few academic converts.

Whether and how soon the American school will atrophy like the British school should depend on the different interactions between the manufacturing sector and academics in the two countries. While the Labour Party and generally left-wing British economists who led the de-industrialization school had little to do with the manufacturing corporations who would profit from a promanufacturing policy, this is not so for the acadernic converts to the de-industrialization school among the new Democrats in the United States. This contrast offers an interesting subject for analysis.

22. Cf. Dornbusch, James Poterba and Lawrence Summers, The Case for Manufacturing in America's Future (Rochester: Eastman Kodak Company, 1988). Since there is yet another Kodak study by Professor Dornbusch, but now with Paul Krugman and Yung Chul Park, Meeting World Challenges: United States Manufacturing in the 1990s (1989), I refer to these hereafter as Kodak I and Kodak II.

23. I return later to the question whether there are such externalities to manufactures.

24. Cf. Kodak I, op. cit., p. 10.

25. Cohen and Zysman, op. cit., p. 16.

26. Bhagwati, Protectionism, op. cit., p. 114.

27. Cf. Kodak I, op. cit, p. 10.

28. See the extended analysis and introduction of these concepts in Bhagwati, 'Splintering and Disembodiment of Services and Developing Nations', The World Economy, June 1984, pp. 133-43. Their implications for the Uruguay Round negotiations are considered in Bhagwati, "Trade in Services and the Multilateral Trade Negotiations', World Bank Economic Review, Washington, No. 4, 1987, pp. 549-69. An excellent analysis of the conceptual issues is also contained in Gary Sampson and Richard Snape, 'Identifying the Issues in Trade in Services', The World Economy, June 1985, pp. 171-82.

29. Pioneered originally by James Brander and Barbara Spencer, the theory has been elegantly developed by Avinash Dixit, Gene Grossman and Jonathan Eaton, among others. Such intervention is called 'strategic' because it involves taking the reactions of oligopolistic foreign firms to one's decisions into account. The 'large-group' case, distinct from the small-group oligopoly case, has also been developed as part of the general interest in market structure and was pioneered by Kelvin Lancaster, Professor Dixit and Joseph Stiglitz, Elhanan Helpman and Paul Krugman. The earliest formal treatments of market structure in international trade began with consideration of pure monopoly: with my analysis of the non-equivalence of tariffs and quotas in the presence of monopoly and with Peter Svedberg and Homi Katrak analyzing the optimal policy for a country faced with a monopolistic supplier. Cf. Bhagwati, 'On the Equivalence of Tariffs and Quotas', in Robert E. Baldwin et al. (eds), Trade, Balance of Payments and Growth: Essays in Honor of Gottfried Haberler (Amsterdam: North-Holland, 1965), and Peter Svedberg. 'Optimal Tariff Policy on Imports from Multinationals', Economic Record, Melbourne, March 1979, pp. 64-67. 
30. This is the conclusion of Lawrence Katz and Summers, 'Industry Rents: Evidence and Implications', Brookings Papers: Microeconomics, No. 2, 1989, pp. 209-75. The paper looks at evidence for 74 manufacturing industries in the United States for 1984.

31. See Ricardo J. Caballero and Richard Lyons, 'The Role of External Economies in United States Manufacturing', mimeograph, Department of Economics, Columbia University, New York, April 1989, and Internal versus External Economies in European Industry, Columbia Discussion Paper No. 426 (New York: Columbia University, 1989). The European countries covered are the Federal Republic of Germany, France, Belgium and the United Kingdom. A similar conclusion is drawn by Dale Jorgenson, Frank Gollop and Barbara Fraumeni, Productivity and United States Economic Growth (Cambridge, Massachusetts: Harvard University Press, 1987) p. 210.

32. This dilemma, where one believes a phenomenon is important but cannot plausibly substantiate it with evidence, recurs often in economics as in other social sciences. Roy Harrod, in his biography of Keynes, recalls how he worked with Lord Cherwell, Prime Minister Churchill's adviser, during the War but resigned and returned to Oxford. He could not tolerate a situation where the physicist wanted to know the dimensions of anything that Harrod would argue to be important. Harrod, like most of us, felt strongly that something was significant, but had no way of measuring and proving it to be so.

33. In my view, the belief that these industries have critical economic externalities, as also the 'non-economic' desire to have a 'modern' economy, is what drives politicians to battles designed to get an appropriate share of these industries. The weapons used are whatever come to hand, including charges of 'unfair trade' practices by successful rivals and an occasional invoking of 'strategic' trade policy.

34. Cf. Caballero and Lyons, op. cit.

35. Adding the total economy as another explanatory variable for output did not improve the explanation over what total manufacturing did. But that suggests that total size of the economy might have worked as well as the size of the manufacturing sector as an explanatory variable signifying externalities.

36. Of course, the theory of non-economic objectives and policy intervention, as developed in the 1960s by W.M. Corden, Harry G. Johnson, Bhagwati and T.N. Srinivasan, Adolf Vandendorpe and others, shows that the optimal subsidy, in case of learning related to manufacturing output, would be to production, not to employment.

37. See, in particular, Robert Rowthorn, 'What Remains of Kaldor's Law?', Economic Journal, Cambridge, March 1975, pp. 10-19; Nicholas Kaldor, 'Economic Growth and the Verdoorn Law - a Comment on Mr Rowthorn's Article', Economic Joumal, December 1975, pp. 891-96; Rowthorn, 'A Reply to Lord Kaldor's Comment', Economic Journal, December 1975, pp. 897-901; and Rowthorn, 'A Note on Verdoorn's Law', Economic Journal, March 1979, pp. 131-33.

The empirical evidence on 'learning by doing' is summarized and extended in Marvin Lieberman, 'The Learning Curve and Pricing in the Chemical Processing Industries', Rand Journai of Economics, Santa Monica, California, No. 2, 1984, pp. 213-28. This article, which is the most careful to date, is however based on price rather than cost data and, more important, does not distinguish between learning by doing related to the output of the firm (which should not produce any market failure unless it is so large relative to market expansion as to make perfect competition unsustainable) and learning by doing related to industry output which it measures (and which may include what I have called 'learning by others' doing' which constitutes an externality leading to market failure in the absence of appropriability).

On the other hand, there is some systematic evidence from the analysis of patent data in the United States that R\&D spill-overs exist across firms, in different industries but in technological space defining 'technological neighbours', and that they will result in higher profits to the beneficiaries of such spill-overs, indicating lack of full appropriability. See Adam Jaffee, 'Technological Opportunity and Spillovers of R\&D: Evidence from Firms' Patents, Profits, and Market Value', American Economic Review, No. 5, 1986, pp. 984-1001. If market failure obtains, with mutual lack of appropriability being unequal among competitive firms undertaking $R \& D$, there would be a case for subsidizing R\&D by the firms that lose on balance from the lack of full appropriability. 
38. This argument has been made by Lawrence Summers.

39. This revival is due to Lawrence Summers who, in papers with Katz, op. cit, and Alan Krueger, 'Efficiency Wages and the Inter-industry Wage Structure', mimeograph, Department of Economics, Harvard University, February 1986, has developed this argument empirically with tenacity and ingenuity.

40. Originating with Mihail Manölesco, the argument was developed in a classic paper by Everett Hagen, 'An Economic Justification of Protectionism', Quarterly Journal of Economics, Cambridge, Massachusetts, November 1958, pp. 496-514. It was then generalized to the theory of domestic distortions and welfare by Bhagwati and V.K. Ramaswami, 'Domestic Distortions, Tariffs and the Theory of Optimum Subsidy', Journal of Political Economy, Chicago, No. 1, 1963, pp. 44-50, culminating in the post-war theory of commercial policy.

41. Quoted from Krugman, 'Is Free Trade Passé?', Journal of Economic Perspectives, Princeton, No. 1, 1987, pp. 131-44. These claims are regrettably without foundation in ignoring the numerous arguments for appropriate trade and domestic interventions that were developed in the post-war theory of commercial policy. They are also dangerous in suggesting to the protectionists that all earlier theoretical arguments were falsely premised: this encourages the populist and Congressional dismissal of the scientific corpus of thought on commercial policy which the new work by no means supplants but only adds to. See Bhagwati, 'Is Free Trade Passé After All?', Bernhard Harms Prize Speech, Weltwirtschafiliches Archiv, Kiel, No. 1, 1989, pp. 3-30.

42. See David G. Tarr, A General Equilibrium Analysis of the Welfare and Employment Effects of United States Quotas in Textiles, Autos and Steel, Bureau of Economics Staff Report to the Federal Trade Commission (Washington: US Government Printing Office, 1989) ch. 8, pp. 6 and 7.

43. Richard Brecher, 'An Efficiency-wage Model of Unemployment in an Open Economy', mimeograph, Department of Economics, Carleton University, Ottawa, March 1989, has examined trade policy when shirking obtains in an otherwise conventional general-equilibrium model. Professor Brecher's theoretical analysis correctly emphasizes that shirking will lead both to higher wage rates to make the penalty of job loss greater if caught and to monitoring costs as well. The higher wage differential is therefore only one consequence; the empirical work must simultaneously look for monitoring costs (which would not show up in this way) if the shirking inference is to be made.

44. Cf. Krueger and Summers, op. cit.

45. Katz and Summers, op. cit., p. 226

46. See, for detailed analysis, Bhagwati and Dougas A. Irwin. 'The Return of the Reciprocitarians: US Trade Policy Today', The World Economy, June 1987, pp. 109-30.

47. Staffan Burenstam Linder, The Pacific Century (Stanford: Stanford University Press, 1986).

48. In some instances, contempt has yielded to fear. Who cannot recall President de Gaulle's disdainful remark about the Japanese Prime Minister: 'Who is this transistor salesman?' The European Community's frenetic use of anti-dumping actions to hold Japanese imports down suggests an altogether changed attitude to the subject matter, as splendidly documented by Brian Hindley, 'Dumping and the Far East Trade of the European Community', The World Economy, December 1988, and Patrick Messerlin, 'The EC Anti-dumping Regulations: a First Economic Appraisal, 1980-85', Weltwirtschaftliches Archiv, No. 3, 1989, and 'GATT-inconsistent Outcomes of GATTconsistent Laws: the Long-term Evolution of the EC Anti-dumping Law', paper for the Trade Policy Research Centre as part of its programme of studies on Regulatory Trade Measures and the Concept of Untair Trade.

49. There are other parallels and contrasts, too, which are analyzed in Bhagwati and Irwin, op. cit.

50. The growth of the export interests in the United States has been noted and analyzed in three independent contributions: Bhagwati, Protectionism, op. cit; Helen Milner, Resisting Protectionism: Global Industries and the Politics of International Trade (Princeton: Princeton University Press, 1988); and I.M. Destler and John Odell, The Politics of Anti-protection (Washington: Institute for International Economics, 1987). While all authors consider the benign role of these interests in shifting trade policy away from import protectionism to exports and 'opening markets', the first 
considers also the down side of the phenomenon - that these export interests may capture trade policy to foster 'export protectionism', as discussed below.

51. For early analyses, see Georgio Basevi, 'Domestic Demand and Ability to Export', Journal of Political Economy, No. 2, 1970, pp. 330-40, and, in particular, Richard Pomfret, 'Some Interrelationships Between Import Substitution and Export Promotion in a Small Open Economy', Weltwirtschaftliches Archiv, No. 4, 1975, pp. 714-27.

52. The permanent advantage results only in the classroom model. In the real world, countless factors are altering the relative fortunes of firms over time, of course. To go from this classroom demonstration of permanent and irreversible advantage to a policy prescription of protection is therefore to make a leap that is not sensible.

53. The scale argument was beautifully formalized in the Brander-Spencer framework by Krugman, 'Import Protection as Export Promotion', in Henryk Kierzkowski (ed.), Monopolistic Competition and International Trade (Oxford: Oxford University Press, 1984).

54. See, in particular, Krugman (ed.), Strategic Trade Policy and the New International Economics (Cambridge, Massachusetts: MIT Press, 1986).

55. History has few recorded cases of unilateral free traders or unilateral trade liberalizations. More common are unilateral trade liberalizations imposed on developing countries as part of conditionality packages attached to IMF and World Bank assistance.

56. Again, there are classroom exceptions leading to paradoxical outcomes.

57. The bargaining of trade concessions has the well-known downside effect that it may induce countries that want to liberalize unilaterally to 'hold back' until they can bargain the trade liberalization instead of 'throwing the chips away'. Also. it may induce countries to impose tariffs in order to acquire chips.

58. Thus Japan could be asked to reduce her trade barriers, because of the latter arguments, even if she did not have a big surplus.

59. There are numerous ways in which one's trade regime can affect investment and savings, in principle. Empirical analysis of many countries' trade and payments policies also suggests many such possibilities, but it also shows that these effects can go in several different directions. Cf. Bhagwati, The Anatomy and Consequences of Exchange Control Regimes (Cambridge, Massachusetts: Ballinger, for the National Bureau of Economic Research, 1978) ch. 6, which reviews the theoretical and empirical findings on the relationship of trade policy to domestic savings. Also see Clarida, op. cit., for other theoretical arguments. And also recall Note 16.

60. The 'scarce-currency' clause at the IMF is a useful precedent of sorts in this regard.

61. These are by Edward Learner and Gary Saxonhouse. See T.N. Srinivasan and Koichi Hamada, 'The United States-Japan Problem', paper presented to the Conference on United States Trade Policy, Columbia University, New York, 8 September 1989. Surprisingly, the report of the Advisory Committee on Trade Negotiations, mentioned at the start, ignores these studies and concentrates instead on the findings of Robert Lawrence, of the Brookings Institution, which are favourable to their recommendations for managed trade with Japan.

62. Of course, economists familiar with ethics allow for meta-preferences - that is, preferences about preferences. If you are a racist, I certainly will not take a 'value-free' position, allowing you free play. But to imagine that the Japanese housewife's preference for Japanese goods falls into this class of meta-preferences is to invite ridicule.

Again, if one recognizes that tastes can be partly endogenous due to advertising and other forms of diffusion of information, one might argue that Japanese housewives have less access to information about foreign goods than the American housewife. But this would be implausible indeed for post-war Japan and for a period when American cultural hegemony has been a source of worldwide concern.

63. Newsweek, New York, 13 February 1989, p. 50.

64. Mordechai E. Kreinin, 'How Closed is Japan's Market? Additional Evidence'. The World Economy, December 1988, pp. 529-42.

65. The closest that anyone came to trying to do this was the German Government in regard to aid-tying. When the United States and the United Kingdom imposed source-tying restrictions on their aid, during their payments-deficit years, the German Finance Ministry tried to avoid similar aid-tying because of the German surplus. In the end, however, it could not because German 
exporters were outraged by the fact that this meant that they were unable to tender for American-aidfinanced contracts while American exporters could tender for German-aid-financed contracts. See the discussion in Bhagwati, 'The Tying of Aid', study prepared for UNCTAD, reprinted in Bhagwati, Dependence and Interdependence: Essays in Development Economics, Vol. 2, edited by Gene Grossman (Oxford: Basil Blackwell, 1985; and Cambridge, Massachusetts: MIT Press, 1985).

66. See, for instance, Paul Blustein, 'Finding a Retirement Home for Japan's "Papa-Mama" Stores', The Washington Post National Weekly, 21-27 August 1989, p. 19. There is disagreement, however, over how restrictive really is the Japanese retail distribution system. See The Economist, 26 August 1989.

67. For example, some countries, and economists, believe that retail price maintenance is a good thing (because, for instance, consumers do not have to shop around). For foreign firms used to the 'orderly' distribution system that also attends such retail price maintenance, the American distribution system may appear too chaotic and difficult to adapt to. Again, within the European Community, the retail distribution systems of member countries exhibit substantial variations, reflecting different cultural, historical and economic factors.

68. Edmund Dell, 'Of Free Trade and Reciprocity'. The World Economy, June 1986, p. 134.

69. Ironically, the original 1955 waiver granted to agriculture by the GATT was to the United States. Equally, the question of trade in services was first raised internationally at UNCTAD rather than at the GATT. How the world changes!

70. On these questions, see the splendid analysis by Martin Wolf, 'Differential and More Favourable Treatment of Developing Countries and the International Trading System', and also Shailendra Anjaria, 'Balance of Payments and Related Issues in the Uruguay Round of Trade Negotiations', World Bank Economic Review, September 1987. This issue contains a Symposium on 'The MTN and Developing Country Interests".

Also see the excellent articles by Isaiah Frank, 'Import Quotas, the Balance of Payments and the GATT', The World Economy, September 1987, pp. 307-18, and Richard Eglin, 'Surveillance of Balance-of-payments Measures in the GATT', The World Economy, March 1987, pp. 1-26.

71. A review of 40 measures by the United States that impede the European Community's exports was released, for instance, in May 1989. See EC News. Washington, No. 13/89, May 1989. The IBRD-UNCTAD index of non-tariff barriers also suggests the same conclusion, although the index has well-known conceptual problems.

72. James Fallows, 'Containing Japan', Atlantic Monthly, May 1989. In his earlier book, More Like Us (Boston: Houghton Mifflin, 1987), Mr Fallows takes the position that the American response to the Japanese challenge should be to improve and strengthen its own institutions along lines more consonant with its flexible and open traditions.

73. This argument has been made by Isaiah Frank.

74. See the report in South China Morning Post, Hong Kong, 21 February 1989, p. 1. In particular: 'There was clear evidence of threats of retaliation by American law firms that Hong Kong would suffer trade restrictions unless the Government allowed foreign lawyers entry.'

75. The concept of VIEs where the importing countries are asked to increase imports of specific items from particular countries by given amounts is the counterpart of the familiar concept of VERs ('voluntary' export restrictions) where exports by these countries are restrained thus. The concept and terminology of VIEs were introduced in Bhagwati, 'VERs, Quid Pro Quo DFI and VIEs: Political-Economy-Theoretic Analyses', International Economic Journal, Seoul, Spring 1987, pp. 1-12, and are further discussed in Bhagwati, Protectionism, op. cit., pp. 82-84.

76. The fact that, thanks to economists' efforts at education, the Office of the United States Trade Representative now is explicit in saying that it will call for non-discriminatory trade concessions under Section-301 and Super-301 procedures does not invalidate the argument in the text as to why Section 301 came to acquire its appeal at the outset. Nor does it assuage the worry that, despite the USTR's present policy, the Section-301 and Super-301 actions will not anyway result in VIEs and trade diversion rather than in trade creation, as discussed later.

77. TRIMs and TRIPs are both acronyms happily suggesting good health and gratification to the harried negotiators in the Uruguay Round talks. 
78. The Jenkins Bill on textiles was defeated. But the launching of the Uruguay Round negotiations did not work to stop the passage of the 1988 Trade Act.

79. For a story on how South Korea planned to do precisely this with her agricultural imports, see Financial Times, 27 April 1987. Also see Bhagwati, Protectionism, op. cit., pp. 82-84, for analysis of the issue, and the recent story in Fortune (27 February 1989, pp. 88-89, story by Rahul Jacob) recording these concerns as well.

80. This was demonstrated in John H. Jackson, 'The General Agreement on Tariffs and Trade in the United States Domestic Law', Michigan Law Review, Ann Arbor, December 1967, pp. 249-332.

81. For an illuminating analysis of Section-30I provisions along these lines, see Robert E. Hudec, 'Thinking About the New Section 301: Beyond Good and Evil', mimeograph, School of Law, University of Minnesota, Minneapolis, 15 June 1989.

82. Claude Barfield Jr has remarked that the Presidential discretion not to take action was built in by the Reagan Administration as a necessary precaution, with the Administration understanding that it would indeed be exercised. On the other hand, the Congressional activists pushing Super 301 believed that Presidential discretion would not be allowed to come in the way of Super-301 actions. The change of Administration, and the greater willingness of President Bush to work in harmony with the Congress, seems to have tilted the balance in favour of the latter presumption, favouring Super-301 actions.

83. Bhagwati, 'Super 301 's Big Bite Flouts the Rules', New York Times, 4 June 1989, and 'Taking the Teeth out of Super 301', World Link, World Economic Forum, July-August 1989, No. $7 / 8$, p. 7 .

84. The fact that Super 301 is an altogether inappropriate instrument for trade liberalization does not mean that the United States or, for that matter, any significant country in world trade should not exercise pressure in appropriate ways for liberalizing trade. The USTR practice of compiling estimates of trade barriers facing the United States, and the European Community's response thereto, is most welcome. So are the annual trade policy reviews of specific countries, starting this year at the GATT. The notion that those opposed to America's unilateral one-on-one tactics are for laissez faire towards foreign trade barriers is based on a non sequitur.

85. See Analysis of the United States-Japan Trade Problem, Report of the Advisory Committee on Trade Negotiations (Washington: USTR, 1989).

86. This is documented by Robert Z. Lawrence, 'Imports in Japan: Closed Markets or Closed Minds?', Brookings Papers on Economic Activity, No. 2, 1987, pp. 523-24. Also see the forceful argumentation in the response to the ACTN Report by the Japan-US Business Council, 'Can a "Results-oriented" Trade Strategy Work?', 26th Conference, San Francisco, 30 June 1989.

87. Even for the more homogeneous case of semi-conductors, the accusations against the Japanese are not overwhelmingly persuasive.

88. For example, how is the target to be set, how is it to be achieved by Japan which is not a centrally-planned economy, how are penalizing tariffs invoked at high levels against Japan (for failure to meet the target increases in imports) to be reconciled with the GA'TT and what would be the reaction of Japan finally to such ham-fisted and authoritarian indulgence of Japan-bashing? None of these considerations has crossed the mind of Rudiger Dornbusch (New York Times, Sunday Business, 24 September 1989) who has recently proposed this form of managed trade. See the devastating critique offered by the economics columnist, Hobart Rowen, in the Washington Post, 24 September 1989.

89. Clyde Prestowitz has even argued that Japan's cultural differences, and the resulting impenetrability of the Japanese market, make Japan surplus-prone (Newsweek, Japan, 1 June 1989). In response (Newsweek, Japan, ibid., and Wall Street Journal, 28 July 1989), I have noted that, in that case, it is astonishing that it took so long since Commodore Perry opened Japan in the nineteenth century for this inevitable surplus to emerge. Sarcasm aside, Japan has run deficits over sustained periods in this century. Nor can anyone ignore the fact that Japan's recent surplus has been great at a time when Japan's cultural differences were being reduced rather than increased. The 'culturalists' who go from culture to surpluses to managed trade need to take a basic course in macro-economics and another in economic history. 
90. See the classic article by Murray Kemp and Henry Wan Jr, 'An Elementary Proposition Concerning the Formation of Customs Unions' (1976), reprinted in Bhagwati (ed.), International Trade: Selected Readings (Cambridge, Massachusetts: MIT Press, 1981).

91. The European Free Trade Association (EFTA), formed almost concurrently with the European Community, was followed by the formation of the Latin American Free Trade Association, which soon came to grief, and in the last half of the 1960s proposals were made for a Pacific free trade area and a North Atlantic one.

92. The issue of trade diversion is not as flimsy as might be imagined just because there were few tariffs between Canada and the United States before the free trade agreement. As David Palmeter has shown, the rules of origin have been drastically changed by the free trade agreement to make protectionist trade diversion easier through arbitrary misuse of the new rules. Cf. Palmeter, 'The FTA Rules of Origin: Boon or Boondogle?', paper presented to the Canadian Centre for Trade Law and Policy, Ottawa, 5 May 1989.

93. I reject therefore not merely the economic logic but also the policy wisdom of the Kodak II recommendations to promote regional and bilateral arrangements because preferential access over other exporting countries (whether efficient suppliers or not) is one of the 'benefits' of such arrangements! By contrast, see the excellent essay on the subject by Michael Aho, 'More Bilateral Trade Agreements Would Be a Blunder: What the Next President Should Do', Cornell International Law Journal, Ithaca, November 1989.

94. The key point is the important, anti-multilateralist signal conveyed by the American conversion to regionalism in the shape of Article XXIV. Regional arrangements of one kind or another, in a wider sense, have always been around and have generally not aroused similar expectations as has the free trade agreement. Thus as J.H. Jackson, World Trade and the Law of GATT (Charlottesville: Michie, 1969), has remarked, 'It has been pointed out that today [1965] more than two thirds of the membership of the GATT are nations that belong to one or another regional arrangement' (p. 588).

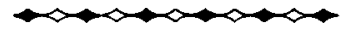 \\ Creative Inertia in Government}

THE following entry for 6 January appeared in the Diaries of James Hacker, Minister for Administrative Affairs, relating to his difficulties with Sir Humphrey Appleby, Permanent Secretary of his Ministry:

'Today, by a lucky chance, I learned a bit about dealing with Sir Humphrey. I bumped into Tom Sargent in the House of Commons smoking room. I asked if I could join him and he was only too pleased.

"“How are you enjoying being in Opposition?" I asked him jocularly.

'Like the good politician he is, he didn't exactly answer my question. "How are you enjoying being in government?" he replied.

'I could see no reason to beat about the bush and I told him that, quite honestly, I'm not enjoying it as much as I'd expected to.

“"Humphrey got you under control?"' he smiled.

'I dodged that one, but said that it's so very hard to get anything done. He nodded, so I asked him, "did you get anything done?"

"“Almost nothing," he replied cheerfully. "But I didn't cotton on to his technique till I'd been there over a year - and then of course there was the election." 
'It emerged from the conversation that the technique in question was Humphrey's system for stalling. According to Tom, it's in five stages. I made a note during our conversation for future reference.

'Stage One: Humphrey will say that the administration is in its early months and there's an awful lot of other things to get on with. (Tom clearly knows his stuff. That is just what Humphrey said to me the day before yesterday.)

'Stage Two: If I persist past Stage One, he'll say that he quite appreciates the intention, something certainly ought to be done - but is this the right way to achieve it?

'Stage Three: If I'm still undeterred he will shift his ground from how I do it to when I do it, i.e. "Minister, this is not the time, for all sorts of reasons."

'Stage Four: Lots of Ministers settle for Stage Three according to Tom. But if not, he will then say that the policy has run into difficulties - technical, political and/or legal. (Legal difficulties are best because they can be made totally incomprehensible and can go on for ever.)

'Stage Five: Finally, because the four stages have taken up to three years, the last stage is to say that "we're getting rather near to the run up to the next general election - so we can't be sure of getting the policy through."

'The stages can be made to last three years because at each stage Sir Humphrey will do absolutely nothing until the Minister chases him. And he assumes, rightly, that the Minister has too much else to do.'

- Jonathan Lynn and Antony Jay, Yes Minister: the Diaries of a Cahinet Minister by the Rt Hon. James Hacker MP, Volume 1 (London: British Broadcasting Corporation, 1981) pp. 90-91.

\section{Lethal Protectionism}

FROM Art Buchwald's column in the International Herald Tribune, Paris, of 24 August 1989:

'President George Bush made a terrible mistake when he banned the importing of foreign semi-automatic guns into the United States. What he did was cut out the Italians, Israelis and Chinese to make sure the American people are supplied with semi-automatic weapons made in the good old USA. The trouble with this is that US manufacturers can't meet the demand and Americans now have to wait months to get the semi-automatic weapons of their dreams.

'The New York Times reports that most domestic manufacturers are working seven days a week to meet the orders and the demand for the guns is at its peak and going higher. I confirmed this when I visited the Sudden Death Gun Company. The owner, Orville Bang, was sweating as he poured grease on the weapons that came off the production line. Between crates he told me that the semi-automatic business has never been better and President Bush was a peach of a guy for keeping the foreign competition out of the US market.' 